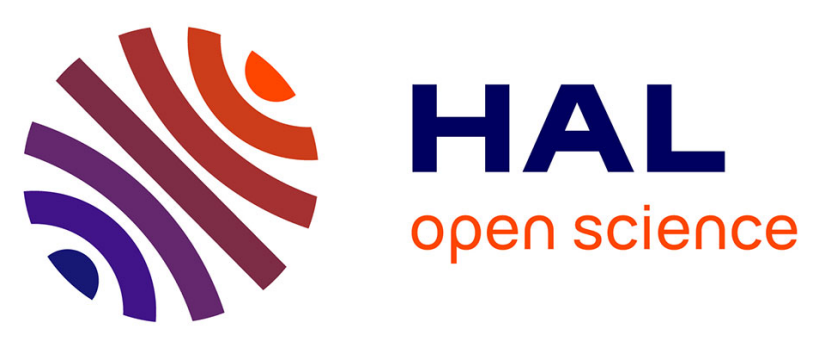

\title{
Coupling 3D groundwater modeling with CFC-based age dating to classify local groundwater circulation in an unconfined crystalline aquifer
}

Tamara Kolbe, Jean Marçais, Zahra Thomas, Jean-Raynald de Dreuzy, Pauline Rousseau-Gueutin, Luc Aquilina, Thierry Labasque, Gilles Pinay

\section{To cite this version:}

Tamara Kolbe, Jean Marçais, Zahra Thomas, Jean-Raynald de Dreuzy, Pauline Rousseau-Gueutin, et al.. Coupling 3D groundwater modeling with CFC-based age dating to classify local groundwater circulation in an unconfined crystalline aquifer. Journal of Hydrology, 2016, RESIDENCE TIMES IN SUBSURFACE HYDROLOGICAL SYSTEMS: Signature of hydrological processes and impact on environmental applications, 543 (Part A), pp.31-46. 10.1016/j.jhydrol.2016.05.020 . insu-01316583

\section{HAL Id: insu-01316583 \\ https://hal-insu.archives-ouvertes.fr/insu-01316583}

Submitted on 17 May 2016

HAL is a multi-disciplinary open access archive for the deposit and dissemination of scientific research documents, whether they are published or not. The documents may come from teaching and research institutions in France or abroad, or from public or private research centers.
L'archive ouverte pluridisciplinaire HAL, est destinée au dépôt et à la diffusion de documents scientifiques de niveau recherche, publiés ou non, émanant des établissements d'enseignement et de recherche français ou étrangers, des laboratoires publics ou privés. 


\section{Accepted Manuscript}

Coupling 3D groundwater modeling with CFC-based age dating to classify local groundwater circulation in an unconfined crystalline aquifer

Tamara Kolbe, Jean Marçais, Zahra Thomas, Benjamin W. Abbott, JeanRaynald de Dreuzy, Pauline Rousseau-Gueutin, Luc Aquilina, Thierry Labasque, Gilles Pinay

PII:

S0022-1694(16)30287-6

DOI: http://dx.doi.org/10.1016/j.jhydrol.2016.05.020

Reference: HYDROL 21264

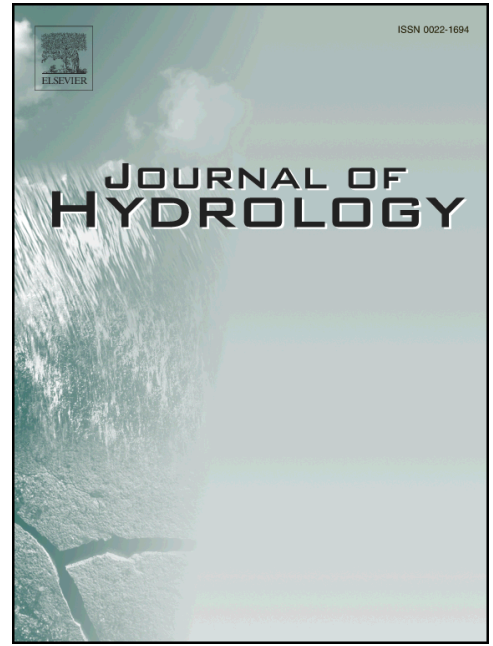

To appear in:

Journal of Hydrology

Please cite this article as: Kolbe, T., Marçais, J., Thomas, Z., Abbott, B.W., de Dreuzy, J-R., Rousseau-Gueutin, P., Aquilina, L., Labasque, T., Pinay, G., Coupling 3D groundwater modeling with CFC-based age dating to classify local groundwater circulation in an unconfined crystalline aquifer, Journal of Hydrology (2016), doi: http:// dx.doi.org/10.1016/j.jhydrol.2016.05.020

This is a PDF file of an unedited manuscript that has been accepted for publication. As a service to our customers we are providing this early version of the manuscript. The manuscript will undergo copyediting, typesetting, and review of the resulting proof before it is published in its final form. Please note that during the production process errors may be discovered which could affect the content, and all legal disclaimers that apply to the journal pertain. 


\title{
Coupling 3D groundwater modeling with CFC-based age dating to classify local
}

\section{groundwater circulation in an unconfined crystalline aquifer}

Tamara Kolbe $^{1}$, Jean Marçais ${ }^{2,1}$, Zahra Thomas ${ }^{3}$, Benjamin W. Abbott ${ }^{4}$, Jean-Raynald de Dreuzy ${ }^{1}$, Pauline Rousseau-Gueutin ${ }^{5}$, Luc Aquilina ${ }^{1}$, Thierry Labasque ${ }^{1}$, Gilles Pinay ${ }^{4}$

${ }^{1}$ Géoscience Rennes, UMRCNRS 6118, Université de Rennes 1, 35042 Rennes Cedex, France

${ }^{2}$ Agroparistech, 16 rue Claude Bernard, 75005 Paris, France

${ }^{3}$ Agrocampus Ouest, Sol Agro et Hydrosystème Spatialisation, 35000 Rennes, France

${ }^{4}$ OSUR, Ecobio, CNRS, Université de Rennes 1, 35042 Rennes Cedex, France

${ }^{5}$ EHESP Rennes, Sorbonne Paris Cité, Paris, France

\begin{abstract}
Nitrogen pollution of freshwater and estuarine environments is one of the most urgent environmental crises. Shallow aquifers with predominantly local flow circulation are particularly vulnerable to agricultural contaminants. Water transit time and flow path are key controls on catchment nitrogen retention and removal capacity, but the relative importance of hydrogeological and topographical factors in determining these parameters is still uncertain. We used groundwater dating and numerical modeling techniques to assess transit time and flow path in an unconfined aquifer in Brittany, France. The $35.5 \mathrm{~km}^{2}$ study catchment has a crystalline basement underneath a $\sim 60 \mathrm{~m}$ thick weathered and fractured layer, and is separated into a distinct upland and lowland area by an $80 \mathrm{~m}$-high butte. We used groundwater discharge and groundwater ages derived from chlorofluorocarbon (CFC) concentration to calibrate a free-surface flow model simulating groundwater flow circulation. We found that groundwater flow was highly local (mean travel distance $=350 \mathrm{~m}$ ), substantially smaller than the typical distance between neighboring streams $(\sim 1 \mathrm{~km})$, while CFC-based ages were quite old (mean $=40$ years). Sensitivity analysis revealed that groundwater travel distances were not sensitive to geological parameters (i.e. arrangement of geological layers and permeability profile) within the
\end{abstract}

\footnotetext{
${ }^{1}$ Corresponding author. Phone: +33223233752
}

Email: Tamara.Kolbe@univ-rennes1.fr 
constraints of the CFC age data. However, circulation was sensitive to topography in the lowland area where the water table was near the land surface, and to recharge rate in the upland area where water input modulated the free surface of the aquifer. We quantified these differences with a local groundwater ratio $\left(r_{\mathrm{GW}-\mathrm{LOCAL}}\right)$, defined as the mean groundwater travel distance divided by the mean of the reference surface distances (the distance water would have to travel across the surface of the digital elevation model). Lowland, $r_{\mathrm{GW}-\mathrm{LOCAL}}$ was near 1 , indicating primarily topographical controls. Upland, $r_{\text {GW-LOCAL was }} 1.6$, meaning the groundwater recharge area is almost twice as large as the topographically-defined catchment for any given point. The ratio $r_{\mathrm{GW}-\mathrm{LOCAL}}$ is sensitive to recharge conditions as well as topography and it could be used to compare controls on groundwater circulation within or between catchments.

Keywords: Transit time distribution, Groundwater travel distance, Groundwater table controls, Groundwater circulation, Small catchment, Crystalline aquifer

\section{Introduction}

Groundwater flow is a key factor in determining the fate of nonpoint source agricultural pollution such as nitrate (Böhlke, 2002; Dunn et al., 2012; Weyer et al., 2014). In contrast with surface flow paths, which can rapidly transport contaminants to streams and rivers, contaminant transport in aquifers is thought to be much slower and to span larger distances, depending on geological structure and hydraulic conductivity (Forster \& Smith, 1988; Grathwohl et al., 2013; McDonnell et al., 2007). These long transit times can enhance biogeochemical alteration of solutes if reactants encounter each other (McClain et al., 2003; Pinay et al., 2015; Vogel et al., 2015). Moreover, the high surface area to volume ratio of the geological substratum in aquifers enhances interactions between water and rock, leading to weathering and chemotrophic metabolism such as autotrophic denitrification of nitrate by pyrite oxidation (Appelo \& Postma, 1994; Engesgaard \& Kipp, 1992). Along with stimulating removal of pollutants, the mixing of multiple water sources can reduce contaminant concentrations by dilution (Chapelle et al., 2009; Green \& Böhlke, 2010). The overall impact of groundwater on the fate of nonpoint source contaminants depends on transit time, location and timing of recharge inputs, and 
internal flow structure either promoting or limiting lateral and vertical exchange in the aquifer. While internal flow structures in the saturated zone are difficult to measure, they can be approximated by mechanistic numerical models, a robust tool to follow water molecules and pollutants through the aquifer, even if they simplify prevailing flow dynamics (Anderson et al., 2015; Bear and Verruijt, 2012).

Groundwater circulation in aquifers has typically been conceptualized in terms of local, intermediate, and regional flow paths (Tóth, 1963; Tóth, 2009). These flow paths contribute differentially to the overall groundwater flow, resulting in a multi-modal distribution of transit times (Cardenas, 2007; Goderniaux et al., 2013). For hard-rock aquifers the majority of groundwater flow occurs in the weathered zone, typically varying from a depth of a few meters to tens of meters, and is characterized by a highly heterogeneous physical structure and variable hydraulic conductivity (Jaunat et al., 2012; Lebedeva et al., 2007; Rempe \& Dietrich, 2014). The fact that the weathered zone overlays the fractured bedrock (Wyns et al., 2004), means that the most active groundwater compartment (and the most vulnerable to pollution) may be conceptualized with only local or local and intermediate flow paths. Topography also has a strong influence on shallow aquifers because the water table is close to the land surface. Consequently, groundwater circulation is controlled by a combination of geologic structure, topographical gradients, and recharge conditions (Freer et al., 1997; Gleeson \& Manning, 2008; Haitjema and Mitchell-Bruker, 2005; McGuire et al., 2005; Tetzlaff et al., 2009). Haitjema and Mitchell-Bruker (2005) developed a criterion for large aquifers to quantify the relative importance of topography and recharge rate in determining water table height (Eq. 1):

$\frac{R L^{2}}{m k H d}>1 \rightarrow$ water table is topography controlled

$\frac{R L^{2}}{m k H d}<1 \quad \rightarrow \quad$ water table is recharge controlled

where $R$ is the effective recharge $\left(\mathrm{m} \mathrm{d}^{-1}\right), L$ is the distance between hydrological boundaries $(\mathrm{m}), m$ is a coefficient equal to 8 for rectangular areas or 16 for circular shapes, $k$ is the hydraulic conductivity ( $\mathrm{m}$ $\left.\mathrm{d}^{-1}\right), H$ is the saturated thickness $(\mathrm{m})$ and $d$ is the maximum terrain raise (m). For a topography controlled groundwater table, local circulation dominates total flow, whereas intermediate and regional 
circulation is predominant in aquifers with a recharge controlled groundwater table (Gleeson and Manning, 2008).

Despite the limited depth of shallow aquifers, groundwater age stratification has been observed based on atmospheric tracers such as chlorofluorocarbons (CFCs) and $\mathrm{SF}_{6}$, providing some important constraints on the flow structure (Ayraud et al., 2008; Busenberg and Plummer, 1992; Cook and Herczeg, 2000). Groundwater age information can be integrated into groundwater models to generate new understanding about the relationship between flow structure and transit time distribution (Cook \& Herczeg, 2000; Eberts et al., 2012; Leray et al., 2012; Molénat \& Gascuel-Odoux, 2002; Molson \& Frind, 2012).

To determine the extent of groundwater flow circulations and to quantify topographical and hydrogeological controls on groundwater flow, we modeled groundwater flow dynamics of a shallow hard-rock aquifer in Brittany France. Given the relatively old observed groundwater ages ( $\sim 40$ years based on CFC concentrations), we hypothesized that groundwater would have traveled long distances from the recharge location to the sampling zone, integrating water recharge from a large area and increasing the likelihood of agricultural contamination. Furthermore, we hypothesized that these travel distances would increase moving from uplands towards lowlands due to the increasing contributing area (catchment size) and the relatively large topographical relief in this catchment. To test these hypotheses, we constructed and calibrated groundwater flow models using geological, topographical, hydrological, and groundwater age data to constrain groundwater transit time distributions, flow line organization, and the distance that groundwater traveled from recharge locations to sampling zones. To test the influence of topography on groundwater circulation, we compared modeled groundwater travel distances with corresponding flow lengths across the digital elevation model (DEM), further called reference distances. Similar reference and groundwater travel distances would suggest strong topographical control on the groundwater table, while relatively longer groundwater travel distances would indicate less connection with the land surface and more of a recharge control on the groundwater table with hydrogeological properties dominating the flow circulation. 


\section{Material and methods}

We performed our study in a $35 \mathrm{~km}^{2}$ agricultural catchment near the town of Pleine-Fougères in Brittany, France (Fig. 1, 48 $36^{\prime} \mathrm{N}, 1^{\circ} 32^{\prime} \mathrm{W}$ ), which is part of the European Long-Term Ecosystem Research network LTER (www.lter-europe.net). Extensive background data from previous studies (Jaunat et al., 2012; Lachassagne et al., 2011; Thomas et al., 2016a) provided physical and chemical constraints allowing the construction of realistic groundwater flow models to test our hypotheses about flow dynamics and transit time distributions. The transit time was defined as the time a water molecule spends between the recharge location and the sampling zone. All transit times of water molecules arriving at the sampling zone were used to calculate the mean transit time of the sample.

\subsection{Pleine-Fougères aquifer}

The Pleine-Fougères aquifer is located in the northern part of the east-west shear zone of the North Armorican Massif (Fig. 1a). This zone is underlain by a crystalline basement (Bernard-Griffiths et al., 1985). The aquifer straddles a geologic transition between granite in the south and schist in the north (Fig. 1b). The unconfined groundwater flow mainly occurs in the weathered zone which overlies a less pervious fractured zone (Jaunat et al., 2012; Lachassagne et al., 2011; Wyns et al., 2004). The mean thickness of the weathered and fractured zone is respectively $9 \mathrm{~m}$ and $48 \mathrm{~m}$, though the thickness of both layers is variable (Fig. 2a, b). Elevation ranges from 9 to 118 m, with most of the relief occurring at a steep slope at the boundary between schist and granite with a mean gradient of $7.5 \%$, creating three distinct landscape components: upland, lowland and the transition area (Fig. 3). Most rivers in the catchment flow from the south to the north. Secondary topographical gradients from the differential incision of rivers are oriented in an east-west direction. Mean groundwater recharge $R$ is estimated at $167 \mathrm{~mm} \mathrm{y}^{-1}$ using meteorological data and the one dimensional Interaction SoilBiosphere-Atmosphere-Model (Boone et al., 1999; Noilhan \& Mahfouf, 1996; Noilhan \& Planton, 1989). We estimated mean annual groundwater discharge, constituting the baseflow at the outlet of the catchment (Fig. 4), at $4.5 \times 10^{6} \mathrm{~m}^{3} \mathrm{y}^{-1}$, based on hydrograph separation of predicted long term stream discharge (mean of $9.1 \mathrm{~m}^{3} \mathrm{y}^{-1}$ ) using a power equation. The hydrograph separation was performed with 
a one-parameter algorithm described in Chapman (1999, Eq. 8), where the baseflow was determined as a simple weighted average of the direct runoff and the baseflow at the previous time interval. In the absence of direct runoff, the baseflow was constant.

\subsection{Groundwater models}

The effective modeled zone $\left(76 \mathrm{~km}^{2}\right)$ was substantially larger than the drainage basin $\left(35 \mathrm{~km}^{2}\right)$ to limit boundary effects. The modeled zone extended beyond the watershed divide in the south (upland) and downslope from the outlet in the north, and was delimited by two rivers in the east and west (Fig. 4). We selected hydraulic conductivities based on average values in the literature (Ayraud et al., 2008; Batu, 1998; Grimaldi et al., 2009; Kovács, 2011), assigning a single conductivity value to each of the four compartments, i.e. weathered schist $\left(K_{\mathrm{WS}}\right)$, fractured schist $\left(K_{\mathrm{FS}}\right)$, weathered granite $\left(K_{\mathrm{WG}}\right)$, and fractured granite $\left(K_{\mathrm{FG}}\right)$. In the reference groundwater model $(\mathrm{REF})$, the hydraulic conductivity of granite was double that of schist $\left(K_{\mathrm{WG}}=2 K_{\mathrm{WS}}\right.$ and $\left.K_{\mathrm{FG}}=2 K_{\mathrm{FS}}\right)$ and the thickness of the weathered and fractured zones was derived from near-surface geologic maps of the area (Fig. 2). We assigned a greater hydraulic conductivity to the weathered granite compared to the hydraulic conductivity in the weathered schist, because of its higher susceptibility to weathering (Bala et al., 2011; Dewandel et al., 2006; Edet and Okereke, 2004). In the calibration procedure, hydraulic conductivities were optimized within a range of $8.64 \times 10^{-2}-1.7 \mathrm{~m} \mathrm{~d}^{-1}$ predetermined by previous studies performed in similar weathered zone aquifers in Brittany (Ayraud et al., 2008; Clement et al., 2003; Le Borgne et al., 2004; Martin et al., 2006; Roques et al., 2014). Due to weathering processes in the weathered zone, porosities up to $50 \%$ are reported in the literature (Kovács, 2011; Wright, 1992). Below the weathered zone, bedrock metamorphic and igneous rocks like schist and granite have a very low primary porosity (0.1 - $1 \%$; Singhal and Gupta, 2013). However, depending on the fracture and fissure density, the porosity in the fractured zone can be up to $10 \%$ (Earle, 2015; Hiscock, 2009). For our models, the effective porosity, i.e. the pore volume that contributes to fluid flow, was set higher in the weathered zone $\left(\theta_{\mathrm{W}}\right)$ than in the fractured zone $\left(\theta_{\mathrm{F}}\right)$ and was assumed to be uniform across both geologies. Values were derived through the calibration against the measured groundwater ages (see section 2.5.). Altogether, the groundwater model was parameterized by $K_{\mathrm{WG}}, K_{\mathrm{FG}}, \theta_{\mathrm{W}}$ and $\theta_{\mathrm{F}}$. All four parameters 
were calibrated against baseflow at the catchment outlet, and groundwater age data estimated using CFC measurements from 9 wells (Fig. 4; see section 2.4 for detailed description of calibration).

In total, five groundwater flow models were developed (Tab. 1). To investigate the influence of weathered zone thickness on groundwater flow, we tested three models with different ratios of weathered to fractured zone thickness. We compared the model with a thin weathered zone, half the thickness of the reference model (THIN), to a model with twice the thickness of the reference model (THICK). For the reference groundwater model (REF), the ratio of the weathered to fractured zone thickness was 0.19 , for the THICK model the ratio was 0.58 , and for the THIN model it was 0.05 . To test our assumptions about differences in hydraulic conductivity between the two geologies, we developed a fourth groundwater model (AHC) with an alternative hydraulic conductivity ratio $\left(K_{\mathrm{WG}}=10 K_{\mathrm{WS}}\right)$, but the same thickness ratio as the reference model. To test the impact of these modifications, we developed a homogeneous model (HOM) that had a uniform hydraulic conductivity and effective porosity. All five models were calibrated using the same procedure, described in detail in section 2.4. The comparison of the reference model with the alternative models is developed in section 3.3.

\subsection{Groundwater flow simulations}

Groundwater flow of the unconfined aquifer was simulated in the $76 \mathrm{~km}^{2}$ flow domain (black dashed rectangle in Fig. 4) under free surface conditions (Bear, 1973). Flow was simulated in steady state, because the groundwater ages measured at high and low groundwater conditions at the site did not show any significant variations (data not shown). Also seasonal recharge variations over 42 years derived from the ISBA model (Boone et al., 1999; Noilhan and Mahfouf, 1996; Noilhan and Planton, 1989) did not show any trend, indicating that transient flow simulations were unnecessary. We applied a uniform recharge of $167 \mathrm{~mm} \mathrm{y}^{-1}$ on the top layer of the model. The effective recharge of $5.8 \times 10^{6} \mathrm{~m}^{3}$ $\mathrm{y}^{-1}$ over the $35.5 \mathrm{~km}^{2}$ catchment is $25 \%$ larger than the discharge of $4.5 \times 10^{6} \mathrm{~m}^{3} \mathrm{y}^{-1}$. This is explained by seepage areas that are not integrated in the discharge computation, which cover $8 \%$ of the land surface. Lateral and bottom boundary conditions were set as no flow. 
Groundwater flow equations with the previously described recharge and boundary conditions were solved with the finite element modeling package FEFLOW (Diersch, 2013). The movable free surface was iteratively determined with the best-adaptation-to-stratigraphic-data technique (BASD), an algorithm that adapts the mesh structure to the free surface height, while respecting as far as possible the layering of the hydraulic conductivity. Because the underlying bedrock at our site had a uniform and very low hydraulic conductivity of $1 \times 10^{9} \mathrm{~m} \mathrm{~d}^{-1}$, it acted effectively as an impervious layer. Its variable thickness gave an overall uniform aquifer domain thickness appropriate for FEFLOW modeling purposes. The mesh generated by FEFLOW contained 6188 triangle prisms per slice, with 2 slices per layer. The vertical discretization was adapted to the weathered zone thickness for each of the different models. The mesh contained 12218 mesh elements per layer, with a total of 122180 mesh elements over 10 layers. The mesh followed surface structures and was automatically refined close to surface waters, where convergence induces larger flows (Fig. 5). The DEM (Fig. 3) shows a marked difference in elevation near channel banks where mesh refinement was implemented.

\subsection{Groundwater flow lines and sampling}

Flow lines were determined using the particle tracking algorithm of FEFLOW (Diersch, 2013), with particles seeded at a density proportional to the imposed recharge at the water table. In order to provide a sufficient representation of the flow field, at least $4 \times 10^{5}$ flow lines were required. Groundwater flow lines in the modeled area are presented in Fig. 6. The red lines mark the seepage zones, which were defined as zones where the groundwater table (extracted from the groundwater flow model) reaches the land surface.

In a post-processing step, we used MATLAB to analyze the flow lines. We created a regular grid of $100 \times 100 \mathrm{~m}$ sampling zones over the whole flow domain and sampled flow lines where they intersected the rectangular columns of the grid at any depth. The selected grid size ensured sufficient flow lines in each sampling zone while avoiding spurious mixing effects. Ultimately model results, e.g. mean transit times, were quite robust to sampling zone size with sensitivity tests revealing little difference between $50 \times 50 \mathrm{~m}$ and $200 \times 200 \mathrm{~m}$ sampling zones sizes (Fig. A.1). The $100 \times 100 \mathrm{~m}$ grid 
over the whole catchment area resulted in sampling zones every $340 \mathrm{~m}$, for a total of 278 sampling zones in the catchment area without considering sampling zones that were located in streams.

\subsection{Calibration}

We used groundwater flow simulations to determine the overall groundwater discharge at the catchment outlet. Hydraulic conductivities $\left(\mathrm{K}_{\mathrm{WG}}\right.$ and $\mathrm{K}_{\mathrm{FG}}$ ) were manually calibrated to fit the observed discharge value of $1.2 \times 10^{4} \mathrm{~m}^{3}$ day $^{-1}$ derived from hydrograph separation.

We estimated the mean groundwater age at the 9 sampling wells with CFC concentrations. CFCs are anthropogenic gases whose atmospheric concentrations increased linearly from 1960 to 1990 (when they were banned) and have been gradually decreasing, allowing the calculation of the average time since a groundwater parcel was in equilibrium with the atmosphere (Ayraud et al., 2008). Groundwater samples were collected in December 2014 and March 2015 and were analyzed at the Geoscience Laboratory (Rennes, France; for detailed methodology see Ayraud et al., 2008; Busenberg and Plummer, 1992 and Cook and Herczeg, 2000). No systematic spatial trends were apparent in the measured groundwater age data from the sampled wells (Fig. 4), so we calibrated the model parameters $\mathrm{K}_{\mathrm{WG}}, \mathrm{K}_{\mathrm{FG}}, \theta_{\mathrm{W}}$ and $\theta_{\mathrm{F}}$ (Table 1) based on the mean and standard deviation of the groundwater age and the discharge (Table 2). The model calibration against the measured mean groundwater age was also done manually. We used the same sampling zone size $(100 \times 100 \mathrm{~m})$ for the 9 wells when calculating modeled groundwater ages. Modeled groundwater ages are the convolution product of the recorded tracer input chronicle and the transit time distribution (Maloszewski and Zuber, 1996; Marçais et al., 2015).

For model calibration this meant reducing hydraulic conductivity decreases the overall discharge and increases the groundwater age or vice versa. As expected, effective porosity did not have any influence on the catchment discharge at steady state conditions, but was positively correlated with the groundwater age. Ratios of effective porosities and hydraulic conductivities were constrained by the dispersion of the groundwater age. All five models were considered to be satisfactory calibrated (Table 2). 


\subsection{Transit time and groundwater travel distance distributions}

For each of the $100 \times 100 \mathrm{~m}$ sampling zones, we derived transit time distributions as well as groundwater travel distance distributions and computed spatial statistics for intersecting flow lines. We computed the transit time for each particle and the mean transit time of all particles reaching the sampling zone. We also calculated the lateral distance traveled by particles intersecting the water column defined by the sampling zone. The groundwater travel distance was defined as the distance from the flow line origin to the center of the sampling zone projected on the ground surface (Fig. 7). These groundwater travel distances were used to build groundwater travel distance distributions and mean groundwater travel distances for each of the 278 sampling zones. We calculated summary statistics for the three catchment areas: upland, transition, and lowland. Because the influence of the topographical transition on transit time and groundwater travel distance distributions extended beyond the steep section of the slope, we defined the transition area as the area extending from the head of the slope to $650 \mathrm{~m}$ to the north of the slope (Fig. 3). Upland and lowland areas were then defined to the south and north of the transition area.

We also compared the groundwater travel distance with the mean distance between two streams, which represented the average Euclidean distance between surface channels calculated with the ArcToolbox of ArcMap (ESRI ® ArcMapTM, 2010).

\subsection{Analysis of groundwater circulation}

To determine the local nature of the groundwater circulation which is related to the groundwater table configuration, we compared groundwater travel distances with reference surface distances. We determined the length of those reference distances as the travel distance water would have traveled along the impermeable ground surface from a topographical height to the sampling zone. We used a 5 m LiDAR DEM with the D8 algorithm implemented in the TopoToolbox Matlab software (Schwanghart and Kuhn, 2010; Schwanghart and Scherler, 2014). Using a D8 algorithm, the flow passes from each cell to its lowest neighboring cell. Reference distances were generated for the whole model domain to calculate mean values for each of the 287 sampling zones $(100 \times 100 \mathrm{~m})$ and summary 
statistics for the upland, transition and lowland area. The comparison of mean groundwater travel distances with mean reference distances was performed for sampling zones with mean distances greater than $100 \mathrm{~m}$ because the mesh size and flow processes that the numerical model accounted for were insufficient for an analysis at a smaller groundwater flow scale (less than $100 \mathrm{~m}$ ).

We used the ratio of mean groundwater travel distance to mean reference distance $\left(r_{\mathrm{GW}-\mathrm{LOCAL}}\right)$ as a metric of the relative influence of topography and recharge on the groundwater table (Fig. 8). Conceptually, when the mean groundwater travel distance is similar to the mean reference distance ( $r_{\mathrm{GW}-\mathrm{LOCAL}}$ approaches 1$)$, the saturated fraction of the subsurface volume (defined as the volume between the land surface and the impermeable bedrock) is higher than $95 \%$. The groundwater table is therefore limited by the land surface and groundwater flow is strongly influenced by topographical gradients (Fig. 8a). When $r_{\mathrm{GW}-\mathrm{LOCAL}}$ is greater than 1, the saturated fraction fills less than $95 \%$ of the subsurface volume, meaning the groundwater table elevation depends mainly on the recharge rate and groundwater flow circulation is dominated by the hydrogeological conditions (Fig. 8c). Fig. 8b demonstrates that locally topography and recharge controls can occur at the same time in an aquifer. We calculated $r_{\mathrm{GW}-\mathrm{LOCAL}}$ based on the average of the mean groundwater travel distances (see section 2.4) and the mean of the reference distances in the upland and lowland area of the aquifer. We did not calculate this ratio for the transition area due to less well-constrained distances and compound uncertainties, meaning that flow lines crossed that zone could not be associated exclusively with the transition area. We also determined the subsurface fraction of subsurface volume for the upland and lowland areas separately. We used this metric at the small catchment scale to quantify groundwater travel distances of local circulation, but it would equally applicable at larger scales where it could be used to classify groundwater circulations in relation to the reference distances.

\section{Results}

In sections 3.1 we present the results of the reference model. In section 3.2 we compare the modeled groundwater travel distances with reference distances and explore their ratio $r_{\mathrm{GW}-\mathrm{LOCAL}}$ in relation to the saturated fraction of the subsurface volume. In section 3.3 we present how modifications in the 
alternative models alter model behavior. Specifically we report the relationship between the groundwater travel distances, transit times, and their spatial arrangement in the catchment.

\subsection{Transit times and groundwater travel distances}

All of the metrics of groundwater travel distance and transit time followed the same pattern, with greatest mean transit times and distances in the transition area, followed by the upland, and then lowland area (Table 3). Mean transit times were on the order of decades, while groundwater travel distances remained on the order of hundreds of meters.

Considering transit time and groundwater travel distance distributions for individual sampling zones of the reference model, Fig. 9 shows distributions for three representative sampling zones in the upland, transition, and lowland area (Fig. 3). The three sampling zones are representative for their area as they show a common shape with an appropriate mean value of all investigated distributions in the related area. In the upland and lowland area, the transit time distributions had an exponential-like shape while the transition zone had a more bimodal shape with maxima around zero and 65 years (Fig. 9a). The mean transit time was 42 years $(\mathrm{SD}=43)$ in the upland sampling zone and 35 years $(\mathrm{SD}=29)$ in the lowland sampling zone. These results were consistent with an exponential distribution, where the mean transit time is equal to the standard deviation, and also with the mean transit time $\tau_{\mathrm{A}}$ given by Haitjema (1995):

$$
\tau_{A}=\frac{\theta \cdot H}{R}
$$

where $\tau_{\mathrm{A}}$ is the mean transit time, $H$ is the mean hydraulic thickness of the aquifer, $\theta$ is the effective porosity and $R$ is the recharge. The mean transit time according to this equation averaged 30 years for the upland area and 16 years for the lowland area when the aquifer thickness was constrained to the weathered zone ( $11.3 \mathrm{~m}$ and $6 \mathrm{~m}$ for the two areas respectively). The mean transit time increased to 74 years upland and 58 years lowland when the aquifer thickness was allowed to include both, the weathered and fractured zones $(60.3 \mathrm{~m}$ and $54 \mathrm{~m}$, respectively). The groundwater travel distance distribution in Fig. 9b resembled an exponential distribution in the upland and transition sampling 
zone. The distance distribution in the lowland sampling zone peaked around $50 \mathrm{~m}$ and only included distances less than $750 \mathrm{~m}$.

The differences of mean transit times and groundwater travel distances for the whole aquifer were visible on the map derived from interpolation of the pointwise values obtained in each sampling zone (Fig. 10a, b). Mean values and the coefficient of variation $(\mathrm{CV})$ of all sampling zones in an area revealed mean transit times of $51(\mathrm{CV}=18 \%), 57(\mathrm{CV}=44 \%)$, and $47(\mathrm{CV}=34 \%)$ years, and mean groundwater travel distances of $326 \mathrm{~m}(\mathrm{CV}=40 \%), 576 \mathrm{~m}(\mathrm{CV}=49 \%)$, and $219 \mathrm{~m}(\mathrm{CV}=59 \%)$ in the upland, transition, and lowland area, respectively. Variability was higher for distances than for times. The transition area had the highest mean groundwater travel distance, though even in this area circulation remained local according to Tóth's flow structure definitions (Tóth, 1963; Tóth, 2009), because flow lines did not extend under any streams. Even the maximum of the mean groundwater travel distances in the three areas were small compared to the size of the catchment $(9 \mathrm{~km}$ from south to north and $5 \mathrm{~km}$ from east to west) at 751, 1 741, and $648 \mathrm{~m}$ in the upland, transition, and lowland area, respectively. The mean distance between two streams was $c a .1000 \mathrm{~m}$ upland and $600 \mathrm{~m}$ lowland indicating a denser stream network in the lowland area. Only $0.1 \%$ of the flow lines connected the upland and lowland area without going under a stream, indicating a dominance of local, rather than intermediate or regional flow. Groundwater flow lines were generally oriented along the east-west direction, except in the transition zone where flow moved primarily from south to north (Fig. 6). Some flow lines intersected the surface along the stream network or just downslope of the steep transition, consistent with observations of springs and surface water in the catchment. The groundwater table was close to the surface, showing groundwater outcropping at $80 \%$ of the total length of the stream channel throughout the catchment, though the groundwater table was more connected with the land surface in the lowland than upland area (Table 4). Some long groundwater flow lines crossed the boundary of the hydrological catchment, but they did not approach the boundary of the modeled domain (Fig. 6). 


\subsection{Groundwater circulation and $r_{\mathrm{GW}-\mathrm{LOCAL}}$}

For the whole aquifer, groundwater circulation remained local with larger groundwater travel distances than the reference distances. Fig. 11 shows the three representative sampling zones for the upland, transition and lowland area of the reference model with the origin of the groundwater and reference flow lines. For the lowland and transition sampling zone, both recharge areas partially overlapped with a larger groundwater recharge area. For the upland sampling zone with higher topographical gradients, recharge areas only overlapped at the sampling zone showing groundwater flow lines and reference flow lines coming from an opposite direction. This is possible because this sampling zone was not in the seepage area and all cases of overlapping and non-overlapping may occur.

The relationship between the ratio $r_{\mathrm{GW}-L O C A L}$ (mean groundwater travel distance divided by the mean of the reference distance) and the proportion of saturated fraction related to the subsurface volume of the reference model revealed different controls for the upland and lowland area (Fig. 12). In the upland area, the saturated fraction filled less than $95 \%$ of the subsurface volume with a ratio $r_{G W-L O C A L}$ of 1.6. The groundwater table was recharge controlled showing larger distances with deeper circulations than in the lowland area. The groundwater flow in the upland area was more influenced by the hydrogeological conditions than the topographical gradients. Groundwater flow was limited by the fresh bedrock which prevented larger circulation. In the lowland area the groundwater table was limited by the topography with the saturated fraction filling more than $95 \%$ of the subsurface volume and a ratio $r_{G W-L O C A L}$ of 1.3. Due to the high groundwater table elevation, the groundwater flow was mainly affected by the topography. Flow lines were shallow and they followed the topographical gradients from the closest topographical height (the recharge location) to the discharge location (sampling zone). For the whole aquifer, $r_{\mathrm{GW}-\mathrm{LOCAL}}$ was 1.7 , meaning that the mean groundwater travel distances were nearly twice as long as the mean of the local reference distances.

\subsection{Alternative models}

To test how our model assumptions influenced the results of the reference model, which indicated that groundwater circulations were local $(<1 \mathrm{~km})$ and mean transit times were quite long (51 years), we 
ran simulations of the four alternative models presented in section 2.2. Our comparison was based on the characteristic mean transit times and mean groundwater travel distances for the full aquifer and the individual upland, transition, and lowland area (Table 3). Despite structural differences, the five models gave similar groundwater table heights, with a maximum mean difference of $2.2 \mathrm{~m}$ between the most different models (REF and AHC), meaning that all five models had a similar aquifer volume.

Mean transit times of the aquifer, like aquifer volumes, given by the five models were less variable than mean groundwater travel distances influenced by permeability and topography structures. Except for the homogeneous model (HOM), mean transit times were similar between models both for the whole aquifer and the individual upland, transition, and lowland areas, though this result is not surprising since all models were calibrated using the same groundwater age data. HOM was different because sampling was performed over the full depth of the model $(90 \mathrm{~m})$, whereas the other models were limited by the impervious bedrock, resulting in a shallower aquifer thickness (around $60 \mathrm{~m}$; Table 3), and in mean transit times that were substantially larger for HOM. While mean transit times were highly sensitive to the overall aquifer volume, mean groundwater travel distances were consistent between models, showing greater sensitivity to topography and geological structure. The alternative hydraulic conductivity model (AHC), which had highly pervious granite upland and less pervious schist lowland showed much larger mean groundwater travel distances upland than the reference model (566 m for AHC and $326 \mathrm{~m}$ for REF; Table 3). Higher permeability in the upland area decreased hydraulic head gradients, resulting in a lower water table for AHC. Consequently, topography played a smaller role and groundwater distances were larger upland. The abrupt reduction of permeability by a factor of 10 from upland to lowland shortened the mean groundwater travel distance in the transition area from $576 \mathrm{~m}$ to $398 \mathrm{~m}$. In the THICK model, with a thicker weathered zone, there was marginally more circulation through the transition area relative to the reference model (639 m vs. $576 \mathrm{~m}$ ) and the opposite effect was observed for the THIN model. However, mean groundwater travel distances were the same or smaller relative to REF in the upland area for both the THICK and THIN model (REF $=326 \mathrm{~m}$, THICK $=296 \mathrm{~m}$, THIN $=313 \mathrm{~m})$. 


\section{Discussion}

In this study we used groundwater flow models of a crystalline unconfined aquifer in Brittany, France to investigate the importance of local flow paths and to identify groundwater table controls at the small catchment scale. We hypothesized that relatively old groundwater would have traveled long distances from the recharge location to the sampling zone with increasing distances towards the catchment outlet. Contrary to our hypothesis we found highly local groundwater flow, with groundwater traveling less than $500 \mathrm{~m}$ on average (Table 3), and groundwater travel distances decreasing moving lowland (Table 3). To localize the flow circulation we used the ratio of groundwater travel distances derived by the numerical model to reference distances from the DEM. Topographical gradients were the major controls on groundwater flow in the lowland area whereas recharge dynamics governed the groundwater table in the upland area with a strong influence of the hydrogeological conditions on groundwater circulation. These results represent a departure from the historical conceptualization of the small-catchment hydrology (Tóth, 1963; Tóth, 2009) with potentially important water source and water quality implications.

\subsection{Patterns of groundwater circulation in shallow aquifers}

Circulation was highly local for all models across a range of weathered and fractured zone thicknesses, not extending below stream beds, indicating a general lack of intermediate and regional flow paths (Gburek and Folmar, 1999). We were particularly interested in identifying mechanisms underlying this behavior, because local groundwater flow is sensitive to local permeability and topography structure, which can be very diverse at the sub-kilometer scale. Several dynamics could explain the contrasting circulation pattern we observed in the upland and lowland area of all models, including the limited aquifer thickness, topographical gradients and groundwater table configuration. The ratio $r_{G W-L O C A L}$ clearly showed a stronger influence of the topography on the flow circulation in the lowland area than in the upland area. Whether linked groundwater travel distances and topographical gradients promote short groundwater flow lines is readily testable and should be confirmed with a more systematic study 
on synthetic topographical structures (Crave \& Davy, 2001; Lague et al., 2000) and by comparing trends in multiple catchments (Thomas et al., 2016b; this issue).

Based on the reference model (REF) we wanted to demonstrate how the ratio $r_{G W-L O C A L}$ and the proportion of the saturated fraction in relation to the subsurface volume evolve under varying recharge and constant hydraulic conductivity conditions (Fig. 13). To analyze the change between recharge and topographical control, we performed simulations with several recharge rates ranging from 1/10 average recharge $\left(16.7 \mathrm{~mm} \mathrm{a}^{-1}\right)$ to 4 times average recharge $\left(668 \mathrm{~mm} \mathrm{a}^{-1}\right)$. Fig. 13 shows how groundwater flow circulation change depending on the groundwater table configuration which is in general related to hydraulic conductivity and the recharge rate. For a four-fold higher recharge rate (Fig. 13a) the groundwater table moved closer to the land surface and flow lines got shorter over the whole domain than for the initial recharge rate $R$ (Fig. 13b), especially in the upland area. Also the flow lines followed more topographical gradients. Under a lesser recharge rate (Fig. 13c) the groundwater table is deeper and less connected to the land surface inducing longer groundwater travel distances. Most of the flow lines that started in the upland area traveled longer distances towards the lowland area. For the three example recharge rates we presented, not only the length of the groundwater travel distances, but also flow directions changed. Under topography controlled conditions (4R, Fig. 13a) flow lines are more east-west oriented due to local topographical roughness, whereas under recharge controlled conditions (R/10, Fig. 13c) flow lines follow the steep slope in south-north direction, again demonstrating the link between hydrogeological and topographical controls. The extent of the hydrogeological active zone varied proportionally to the induced recharge rate and the limiting depth coming from the unaltered bedrock. Particularly in the upland area, the groundwater table elevation was more susceptible to changes in recharge and deeper flow lines were limited by the fresh bedrock.

We propose the ratio of groundwater travel distance to reference distance $\left(\mathrm{r}_{\mathrm{GW}-\mathrm{LOCAL}}\right)$ as a useful tool to quantify the spatial extent of the groundwater circulation. The evolution of $r_{\mathrm{GW}-\mathrm{LOCAL}}$ with the proportion of the saturated fraction in relation to the subsurface volume at differing recharge levels give an indication of the recharge versus topography controls on the groundwater table and therefore 
on flow dynamics (Fig. 14). The ratio $r_{\mathrm{GW}-\mathrm{LOCAL}}$ decreased as the saturated fraction increased, reaching 1 when the saturated fraction exceeded $95 \%$ of the subsurface volume. This meant that when the aquifer filled the whole subsurface volume (groundwater table at the land surface), groundwater distances became similar to reference distances derived by the DEM, and topography mainly influenced the groundwater circulation. By contrast, a recharge controlled regime developed as the saturated fraction decreased and $r_{\mathrm{GW}-\mathrm{LOCAL}}$ became larger than $1 . r_{\mathrm{GW}-\mathrm{LOCAL}}$ decreased linearly with an increase of the saturated fraction despite increasing dispersion, i.e. longer flow lines due to greater distances between the land surface and the water table. The ratio $r_{\text {GW-LOCAL }}$ showed a distinct asymptotic behavior for the upland and lowland area. While the overall pattern was similar, the ratio $r_{\mathrm{GW}-\mathrm{LOCAL}}$ responded more strongly to changes in the extent of the saturated fraction in the upland area. This suggest two distinct regimes, one for the upland and the other for the lowland area (Fig. 14). The ratio $r_{\mathrm{GW}-\mathrm{LOCAL}}$ varied strongly ranging from 0.03 to 7.47 (lower quartile $=1.0$ and upper quartile 2.2 ) dependent on the applied recharge rate, though the groundwater travel distance with their respective transit times remained larger than the reference distances in most areas. These results underline the need for a local analysis of groundwater table controls in small catchments and provide the ratio $r_{\mathrm{GW}}$ LOCAL to perform this analysis. While the criterion of Haitjema and Mitchell-Bruker (2005) is relevant to quantify topography and recharge controls at larger scales, our criterion is appropriate at smaller scales and for shallow aquifers.

\subsection{What does old and local flow mean for water quality?}

Our results revealed that groundwater mean transit times and groundwater travel distances in this aquifer do not fit within the concept of local, intermediate and regional groundwater flow (Tóth, 1963; Tóth, 2009) but that the majority of groundwater occurred within the shallow, weathered zone. While flow remained local, mean transit times were surprisingly long with mean transit times greater than 50 years. These mean transit times are much larger than values typically used in models forecasting water quality in shallow aquifers (Ayraud et al., 2008; Molénat et al., 2013). One of the implications of this finding is that any changes in land use or agricultural practice may take decades to influence groundwater quality. This time-lag between changes in management and potential improvements of 
water quality, complicates the evaluation of the efficacy of efforts to protect water quality such as fertilizer reduction or land cover change because cause and effect are so temporally separated. Current water quality should therefore be related to past land-use and the duration of monitoring programs should be scaled depending on the distribution of transit times. Another implication of the long mean transit times observed here is that trends in groundwater quality could be influenced by long-term changes in water balance. Because the rate of recovery of a polluted aquifer depends largely on water turnover time, changes in groundwater recharge resulting from shifts in precipitation and evapotranspiration could strongly influence groundwater chemistry independent of any changes in land management. Marked latitudinal differences in climate projections of water balance in Europe (Forzieri et al., 2014) suggest a shortening of transit times (and associated recovery times) in northern Europe and a lengthening of transit times in southern Europe.

The second finding, that most groundwater stays highly local, travelling an average of less than $500 \mathrm{~m}$ from where it entered the aquifer, reinforces the importance of addressing groundwater quality at highly local scales including plot-level scales of individual fields. The topography and recharge control on the groundwater table and therefore on groundwater travel distances during high and low flows, suggests that a reconsideration is warranted of the role of landscape features such as riparian zones, hedgerows, and groundwater surface water exchange zones in mitigating diffuse nitrogen pollution originating from groundwater via a temporally dynamic modelling approach. On a general note, it is worthwhile to notice that the transit time and travel distance distributions could not have been derived from each other because of their different shapes (i.e. independent modelling of these parameters were necessary). Only both distributions together reveal detailed information about the water source and the time spent in the aquifer.

Our results highlight several interesting phenomena regarding groundwater dynamics in shallow aquifers. In surface waters such as rivers and streams, water comes from large catchments very quickly, while groundwater systems in small catchments have old water coming from very local sources. The surface water contributing area increases moving downstream as catchment size increases. Conversely, from our study and other recent work (Gburek and Folmar, 1999), groundwater 
"catchments" seem to stay the same size or even decrease moving downslope, due to shifts in topographical controls and recharge dynamics. These distinct hydrological and landscape-level patterns mean that surface waters are more likely to be impacted by acute or diffuse pollution since they drain a larger region, but that quick transit time and small water volume mean contaminants can quickly be transported away or diluted. Groundwater systems are much more modular and are therefore potentially less likely to experience pollution. However, if there is a local contaminant source, long transit times and limited long-distance water exchange means that the impact may be extreme and long-lasting.

\section{Conclusion}

The comprehensive analysis of several numerical groundwater flow models developed for a shallow hard-rock aquifer in Brittany, France gave insights in internal flow structures that are impossible to measure in the field. The unconfined aquifer was dominated by local flow circulation that was more vulnerable to contamination than deeper flows. The mean length of groundwater flow paths was limited to a few hundred meters $(334 \mathrm{~m})$, while the mean transit times were on the order of decades (51 y). A clear distinction could be drawn between the upland, transition, and lowland area for flow circulation and mean transit times, with greatest mean transit times and mean groundwater travel distances in the transition area followed by the upland and then the lowland area. Transit time distributions had an exponential-like distribution in the upland and lowland area, whereas the transition area showed a bimodal distribution. An examination of circulation in the upland and lowland area revealed distinct controls on the groundwater table and therefore on the flow behavior despite identical recharge conditions. We proposed the ratio $r_{\mathrm{GW}-\mathrm{LOCAL}}$ as an index of whether the groundwater table is limited by the topography or determined by the recharge rate at the small catchment scale, complementing the regional criterion of Haitjema and Mitchell-Bruker (2005; see Eq. 1). At this site, the ratio $r_{\mathrm{GW}-\mathrm{LOCAL}}$ has proved a robust tool to describe the extent of groundwater circulation, and its generality should be tested between catchments (Thomas et al., 2016b; this issue).

\section{Acknowledgements}


Financial support for this research was provided by the European Union's Seventh Framework for research, technological development and demonstration under grant agreement no. 607150. The authors are grateful to the Marie Curie Actions for funding this research. This paper was supported by the European Union International Training Network "INTERFACES: Ecohydrological interfaces as critical hotspots for transformations of ecosystem exchange fluxes and biogeochemical cycling". The authors acknowledge MIKE Powered by DHI for sponsoring the license file for the MIKE Powered by DHI Software - FEFLOW. We further acknowledge the French Geological Survey (BRGM) for providing geological maps of the study site and the AquiFR project for developing and gathering Aquifer models in France. This work was also supported by the French National Program EC2CO Continental and Coastal Ecosphere. We also acknowledge the LTER Zone Atelier Armorique. The authors would like to thank the anonymous reviewers for their valuable comments and suggestions to improve the quality of the paper. 


\section{References}

Anderson, M.P., Woessner, W.W., Hunt, R.J., 2015. Applied Groundwater Modeling: Simulation of Flow and Advective Transport. Elsevier Science.

Appelo, C., Postma, D., 2005. Geochemistry Groundwater and Pollution., 2nd ed. A.A. Balkema Publishers, Leiden, The Netherlands a member of the Taylor \& Francis Group plc.

Ayraud, V., Aquilina, L., Labasque, T., Pauwels, H., Molenat, J., Pierson-Wickmann, A.C., Durand, V., Bour, O., Tarits, C., Le Corre, P., Fourre, E., Merot, P., Davy, P., 2008. Compartmentalization of physical and chemical properties in hard-rock aquifers deduced from chemical and groundwater age analyses. Appl. Geochemistry 23, 2686-2707. doi:10.1016/j.apgeochem.2008.06.001

Bala, A., Eduvie, O., Byami, J., 2011. Borehole depth and regolith aquifer hydraulic characteristics of bedrock types in Kano area, Northern Nigeria. African J. Environ. Sci. Technol. doi:10.4314/ajest.v5i3.71936

Batu, V., 1998. Aquifer hydraulics: a comprehensive guide to hydrogeologic data analysis, 1 st ed. Wiley Interscience.

Bear, J., 1973. Dynamics of Fluids in Porous Media. American Elsevier Publishing Company, inc.

Bear, J., Verruijt, A., 2012. Modeling Groundwater Flow and Pollution. Springer Science \& Business Media.

Bernard-Griffiths, J., Peucat, J.J., Sheppard, S., Vidal, P., 1985. Petrogenesis of Hercynian leucogranite from the southern armorican massif : contribution of REE and isotopic ( $\mathrm{Sr}$, $\mathrm{Nd}, \mathrm{Pb}$ and $\mathrm{O}$ ) geochemical data to the study of source rock characteristics and ages. Earth Planet. Sci. Lett. 74, 235-250. doi:10.1016/0012-821X(85)90024-X

Böhlke, J.-K., 2002. Groundwater recharge and agricultural contamination. Hydrogeol. J. 10, 153-179. doi:10.1007/s10040-001-0183-3

Boone, A., Calvet, J.-C., Noilhan, J., 1999. Inclusion of a Third Soil Layer in a Land Surface Scheme Using the Force-Restore Method. J. Appl. Meteorol. 38, 1611-1630. doi:10.1175/1520-0450(1999)038<1611:IOATSL>2.0.CO;2

Busenberg, E., Plummer, L.N., 1992. Use of chlorofluorocarbons (CCl 3 F and CCl 2 F 2 ) as hydrologic tracers and age-dating tools: The alluvium and terrace system of central Oklahoma. Water Resour. Res. 28, 2257-2283. doi:10.1029/92WR01263

Cardenas, M.B., 2007. Potential contribution of topography-driven regional groundwater flow to fractal stream chemistry: Residence time distribution analysis of Tóth flow. Geophys. Res. Lett. 34, L05403. doi:10.1029/2006GL029126

Chapelle, F.H., Bradley, P.M., Goode, D.J., Tiedeman, C., Lacombe, P.J., Kaiser, K., Benner, R., 2009. Biochemical Indicators for the Bioavailability of Organic Carbon in Ground Water. Ground Water 47, 108-121. doi:10.1111/j.1745-6584.2008.00493.x

Chapman, T., 1999. A comparison of algorithms for streamflow recession and baseflow separation. Hydrol. Process. 13, 701-714. doi:10.1002/(SICI)10991085(19990415)13:5<701::AID-HYP774>3.0.CO;2-2

Clement, J.C., Aquilina, L., Bour, O., Plaine, K., Burt, T.P., Pinay, G., 2003. Hydrological 
flowpaths and nitrate removal rates within a riparian floodplain along a fourth-order stream in Brittany (France). Hydrol. Process. 17, 1177-1195. doi:10.1002/hyp.1192

Cook, P.G., Herczeg, A.L., 2000. Environmental tracers in subsurface hydrology. Springer US.

Crave, A., Davy, P., 2001. A stochastic "precipiton" model for simulating erosion/sedimentation dynamics. Comput. Geosci. 27, 815-827. doi:10.1016/S00983004(00)00167-9

Dewandel, B., Lachassagne, P., Wyns, R., Marechal, J.C., Krishnamurthy, N.S., 2006. A generalized 3-D geological and hydrogeological conceptual model of granite aquifers controlled by single or multiphase weathering. J. Hydrol. 330, 260-284. doi:10.1016/j.jhydrol.2006.03.026

Diersch, H.-J., 2013. FEFLOW: Finite Element Modeling of Flow, Mass and Heat Transport in Porous and Fractured Media. Springer Science \& Business Media.

Dunn, S.M., Darling, W.G., Birkel, C., Bacon, J.R., 2012. The role of groundwater characteristics in catchment recovery from nitrate pollution. Hydrol. Res. 43, 560. doi: $10.2166 /$ nh. 2012.020

Earle, S., 2015. Physical Geology. BC Open Textbooks.

Eberts, S.M., Böhlke, J.K., Kauffman, L.J., Jurgens, B.C., 2012. Comparison of particletracking and lumped-parameter age-distribution models for evaluating vulnerability of production wells to contamination. Hydrogeol. J. 20, 263-282. doi:10.1007/s10040-0110810-6

Edet, A., Okereke, C., 2004. Hydrogeological and hydrochemical character of the regolith aquifer, northern Obudu Plateau, southern Nigeria. Hydrogeol. J. 13, 391-415. doi:10.1007/s10040-004-0358-9

Engesgaard, P., Kipp, K., 1992. A geochemical transport model for redox-controlled movement of mineral fronts in groundwater flow systems: A case of nitrate removal by oxidation of pyrite. Water Resour. Res. 28, 2829-2843. doi:10.1029/92wr01264

ESRI 2011. ArcGIS Desktop: Release 10. Redlands, CA: Environmental Systems Research Insitute, n.d.

Forster, C., Smith, L., 1988. Groundwater flow systems in mountainous terrain: 2. Controlling factors. Water Resour. Res. 24, 1011-1023. doi:10.1029/WR024i007p01011

Forzieri, G., Feyen, L., Rojas, R., Flörke, M., Wimmer, F., Bianchi, A., 2014. Ensemble projections of future streamflow droughts in Europe. Hydrol. Earth Syst. Sci. 18, 85108. doi:10.5194/hess-18-85-2014

Freer, J., McDonnell, J., Beven, K.J., Brammer, D., Burns, D., Hooper, R.P., Kendal, C., 1997. Topographic controls on subsurface stormflow at the hillslope scale for two hydrologically distinct small catchments. Hydrol. Process. 11, 1347-1352. doi:10.1002/(SICI)1099-1085(199707)11:9<1347::AID-HYP592>3.3.CO;2-I

Gburek, W.J., Folmar, G.J., 1999. Patterns of contaminant transport in a layered fractured aquifer. J. Contam. Hydrol. 37, 87-109. doi:10.1016/S0169-7722(98)00158-2

Gleeson, T., Manning, A.H., 2008. Regional groundwater flow in mountainous terrain: Threedimensional simulations of topographic and hydrogeologic controls. Water Resour. Res. 44, W10403. doi:10.1029/2008WR006848 
Goderniaux, P., Davy, P., Bresciani, E., de Dreuzy, J.-R., Le Borgne, T., 2013. Partitioning a regional groundwater flow system into shallow local and deep regional flow compartments. Water Resour. Res. 49, 2274-2286. doi:10.1002/wrcr.20186

Grathwohl, P., Rügner, H., Wöhling, T., Osenbrück, K., Schwientek, M., Gayler, S., Wollschläger, U., Selle, B., Pause, M., Delfs, J.-O., Grzeschik, M., Weller, U., Ivanov, M., Cirpka, O.A., Maier, U., Kuch, B., Nowak, W., Wulfmeyer, V., Warrach-Sagi, K., Streck, T., Attinger, S., Bilke, L., Dietrich, P., Fleckenstein, J.H., Kalbacher, T., Kolditz, O., Rink, K., Samaniego, L., Vogel, H.-J., Werban, U., Teutsch, G., 2013. Catchments as reactors: a comprehensive approach for water fluxes and solute turnover. Environ. Earth Sci. 69, 317-333. doi:10.1007/s12665-013-2281-7

Green, C.T., Böhlke, J.K., Bekins, B.A., Phillips, S.P., 2010. Mixing effects on apparent reaction rates and isotope fractionation during denitrification in a heterogeneous aquifer. Water Resour. Res. 46, 1-19. doi:10.1029/2009WR008903

Grimaldi, C., Thomas, Z., Fossey, M., Fauvel, Y., Merot, P., 2009. High chloride concentrations in the soil and groundwater under an oak hedge in the West of France: an indicator of evapotranspiration and water movement. Hydrol. Process. 23, 1865-1873. doi:10.1002/hyp.7316

Haitjema, H.M., 1995. On the residence time distribution in idealized groundwatersheds. J. Hydrol. 172, 127-146. doi:10.1016/0022-1694(95)02732-5

Haitjema, H.M., Mitchell-Bruker, S., 2005. Are water tables a subdued replica of the topography? Ground Water 43, 781-786. doi:10.1111/j.1745-6584.2005.00090.x

Hiscock, K.M., 2009. Hydrogeology: Principles and Practice. John Wiley \& Sons.

Jaunat, J., Huneau, F., Dupuy, a., Celle-Jeanton, H., Vergnaud-Ayraud, V., Aquilina, L., Labasque, T., Le Coustumer, P., 2012. Hydrochemical data and groundwater dating to infer differential flowpaths through weathered profiles of a fractured aquifer. Appl. Geochemistry 27, 2053-2067. doi:10.1016/j.apgeochem.2012.06.009

Kovács, G., 2011. Seepage Hydraulics. Elsevier.

Lachassagne, P., Wyns, R., Dewandel, B., 2011. The fracture permeability of Hard Rock Aquifers is due neither to tectonics, nor to unloading, but to weathering processes. Terra Nov. 23, 145-161. doi:10.1111/j.1365-3121.2011.00998.x

Lague, D., Davy, P., Crave, A., 2000. Estimating uplift rate and erodibility from the areaslope relationship: Examples from Brittany (France) and numerical modelling. Phys. Chem. Earth, Part A Solid Earth Geod. 25, 543-548. doi:10.1016/S14641895(00)00083-1

Le Borgne, T., Bour, O., de Dreuzy, J.R., Davy, P., Touchard, F., 2004. Equivalent mean flow models for fractured aquifers: Insights from a pumping tests scaling interpretation. Water Resour. Res. 40, W03512. doi:10.1029/2003WR002436

Lebedeva, M.I., Fletcher, R.C., Balashov, V.N., Brantley, S.L., 2007. A reactive diffusion model describing transformation of bedrock to saprolite. Chem. Geol. 244, 624-645. doi:10.1016/j.chemgeo.2007.07.008

Leray, S., de Dreuzy, J.-R., Bour, O., Labasque, T., Aquilina, L., 2012. Contribution of age data to the characterization of complex aquifers. J. Hydrol. 464-465, 54-68. doi:10.1016/j.jhydrol.2012.06.052

Maloszewski, P., Zuber, A., 1996. Lumped parameter models for the interpretation of 
environmental tracer data.

Marçais, J., de Dreuzy, J.-R., Ginn, T.R., Rousseau-Gueutin, P., Leray, S., 2015. Inferring transit time distributions from atmospheric tracer data: Assessment of the predictive capacities of Lumped Parameter Models on a 3D crystalline aquifer model. J. Hydrol. 525, 619-631. doi:10.1016/j.jhydrol.2015.03.055

Martin, C., Molenat, J., Gascuel Odoux, C., Vouillamoz, J.-M., Robain, H., Ruiz, L., Faucheux, M., Aquilina, L., 2006. Modelling the effect of physical and chemical characteristics of shallow aquifers on water and nitrate transport in small agricultural catchments. J. Hydrol. 326, 25-42. doi:10.1016/j.jhydrol.2005.10.040

MATLAB and Statistics Toolbox Release 2013b, The MathWorks, Inc., Natick, Massachusetts, United States, n.d.

McClain, M.E., Boyer, E.W., Dent, C.L., Gergel, S.E., Grimm, N.B., Groffman, P.M., Hart, S.C., Harvey, J.W., Johnston, C. a., Mayorga, E., McDowell, W.H., Pinay, G., 2003. Biogeochemical Hot Spots and Hot Moments at the Interface of Terrestrial and Aquatic Ecosystems. Ecosystems 6, 301-312. doi:10.1007/s10021-003-0161-9

McDonnell, J.J., Sivapalan, M., Vaché, K., Dunn, S., Grant, G., Haggerty, R., Hinz, C., Hooper, R., Kirchner, J., Roderick, M.L., Selker, J., Weiler, M., 2007. Moving beyond heterogeneity and process complexity: A new vision for watershed hydrology. Water Resour. Res. 43, W07301. doi:10.1029/2006WR005467

McGuire, K.J., McDonnell, J.J., Weiler, M., Kendall, C., McGlynn, B.L., Welker, J.M., Seibert, J., 2005. The role of topography on catchment-scale water residence time. Water Resour. Res. 41, 1-14. doi:10.1029/2004WR003657

Molénat, J., Gascuel-Odoux, C., 2002. Modelling flow and nitrate transport in groundwater for the prediction of water travel times and of consequences of land use evolution on water quality. Hydrol. Process. 16, 479-492. doi:10.1002/hyp.328

Molénat, J., Gascuel-Odoux, C., Aquilina, L., Ruiz, L., 2013. Use of gaseous tracers (CFCs and SF6) and transit-time distribution spectrum to validate a shallow groundwater transport model. J. Hydrol. 480, 1-9. doi:10.1016/j.jhydrol.2012.11.043

Molson, J.W., Frind, E.O., 2012. On the use of mean groundwater age, life expectancy and capture probability for defining aquifer vulnerability and time-of-travel zones for source water protection. J. Contam. Hydrol. 127, 76-87. doi:10.1016/j.jconhyd.2011.06.001

Noilhan, J., Mahfouf, J.F., 1996. The ISBA land surface parameterisation scheme. Glob. Planet. Change 13, 145-159. doi:10.1016/0921-8181(95)00043-7

Noilhan, J., Planton, S., 1989. A Simple Parameterization of Land Surface Processes for Meteorological Models. Mon. Weather Rev. 117, 536-549. doi:10.1175/15200493(1989) 117<0536:ASPOLS>2.0.CO;2

Pinay, G., Peiffer, S., De Dreuzy, J.-R., Krause, S., Hannah, D.M., Fleckenstein, J.H., Sebilo, M., Bishop, K., Hubert-Moy, L., 2015. Upscaling Nitrogen Removal Capacity from Local Hotspots to Low Stream Orders' Drainage Basins. Ecosystems 18, 1101-1120. doi:10.1007/s10021-015-9878-5

Rempe, D.M., Dietrich, W.E., 2014. A bottom-up control on fresh-bedrock topography under landscapes. Proc. Natl. Acad. Sci. U. S. A. 111, 6576-6581. doi:10.1073/pnas.1404763111

Roques, C., Aquilina, L., Bour, O., Maréchal, J.-C., Dewandel, B., Pauwels, H., Labasque, T., 
Vergnaud-Ayraud, V., Hochreutener, R., 2014. Groundwater sources and geochemical processes in a crystalline fault aquifer. J. Hydrol. 519, 3110-3128. doi:10.1016/j.jhydrol.2014.10.052

Schwanghart, W., Kuhn, N.J., 2010. TopoToolbox a set of Matlab functions for topographic analysis. Environ. Model. Softw. 770-781.

Schwanghart, W., Scherler, D., 2014. Short Communication: TopoToolbox 2 - MATLABbased software for topographic analysis and modeling in Earth surface sciences. Earth Surf. Dyn. 2, 1-7. doi:10.5194/esurf-2-1-2014

Singhal, B.B.S., Gupta, R.P., 2013. Applied Hydrogeology of Fractured Rocks. Springer Science \& Business Media.

Tetzlaff, D., Seibert, J., Soulsby, C., 2009. Inter-catchment comparison to assess the influence of topography and soils on catchment transit times in a geomorphic province; the Cairngorm mountains, Scotland. Hydrol. Process. 23, 1874-1886. doi:10.1002/hyp.7318

Thomas, Z., Abbott, B., Troccaz, O., Baudry, J., Pinay, G., 2016a. Proximate and ultimate controls on carbon and nutrient dynamics of small agricultural catchments. doi:10.5194/bg-13-1863-2016

Thomas, Z., Rousseau-Gueutin, P., Kolbe, T., Abbott, B.W., Marçais, J., Peiffer, S., Frei, S., Bishop, K., Pinay, G., Pichelin, P., de Dreuzy, J.-R., 2016b. Residence Time Distribution in small catchments: constitution of a virtual observatory to assess generic flow and transport models. J. Hydrol.

Tóth, J., 2009. Gravitational Systems of Groundwater Flow. Cambridge University Press. doi:10.1017/CBO9780511576546

Tóth, J., 1963. A theoretical analysis of groundwater flow in small drainage basins. J. Geophys. Res. 68, 4795-4812. doi:10.1029/JZ068i016p04795

Vogel, L.E., Makowski, D., Garnier, P., Vieublé-Gonod, L., Coquet, Y., Raynaud, X., Nunan, N., Chenu, C., Falconer, R., Pot, V., 2015. Modeling the effect of soil meso- and macropores topology on the biodegradation of a soluble carbon substrate. Adv. Water Resour. 83,123-136. doi:10.1016/j.advwatres.2015.05.020

Weyer, C., Peiffer, S., Schulze, K., Borken, W., Lischeid, G., 2014. Catchments as heterogeneous and multi-species reactors: An integral approach for identifying biogeochemical hot-spots at the catchment scale. J. Hydrol. 519, 1560-1571. doi:http://dx.doi.org/10.1016/j.jhydrol.2014.09.005

Wright, E.P., Burgess, W.G., 1992. The hydrogeology of crystalline basement aquifers in Africa. Geol. Soc. Spec. Publ. 1-27.

Wyns, R., Baltassat, J.M., Lachassagne, P., Legchenko, A., Vairon, J., Mathieu, F., 2004. Application of proton magnetic resonance soundings to groundwater reserve mapping in weathered basement rocks (Brittany, France). Bull. La Soc. Geol. Fr. 175, 21-34. doi: $10.2113 / 175.1 .21$ 


\begin{tabular}{|c|c|c|c|c|c|c|}
\hline & & REF & THICK & THIN & AHC & HOM \\
\hline \multirow{2}{*}{$K_{\mathrm{W}}\left[\mathrm{m} \mathrm{d}^{-1}\right]$} & $\mathrm{G}$ & 0.68 & 0.3 & 0.68 & 2 & 0.15 \\
\hline & $\mathrm{S}$ & 0.34 & 0.6 & 0.34 & 0.2 & 0.15 \\
\hline \multirow{2}{*}{$K_{\mathrm{F}}\left[\mathrm{m} \mathrm{d}^{-1}\right]$} & $\mathrm{G}$ & 0.34 & 0.15 & 0.34 & 1 & 0.15 \\
\hline & $S$ & 0.17 & 0.3 & 0.17 & 0.1 & 0.15 \\
\hline \multirow{2}{*}{$H_{\mathrm{W}, \text { mean }}[\mathrm{m}]$} & $\mathrm{G}$ & 11.3 & 19.5 & 3.7 & 22.3 & \multirow{6}{*}{90} \\
\hline & S & 6.6 & 22 & 1.9 & 4.3 & \\
\hline \multirow{2}{*}{$H_{\mathrm{F}, \text { mean }}[\mathrm{m}]$} & G & 49.3 & 37.1 & 56.3 & 42.8 & \\
\hline & $S$ & 47.4 & 34.8 & 51.7 & 43.4 & \\
\hline \multirow{2}{*}{$H_{\mathrm{B}, \text { mean }}[\mathrm{m}]$} & G & 30.6 & 35.4 & 31.3 & 23.8 & \\
\hline & S & 34.5 & 30.4 & 34.9 & 41.5 & \\
\hline$\theta_{\mathrm{W}}[-]$ & $\mathrm{G}, \mathrm{S}$ & 0.45 & 0.45 & 0.55 & 0.45 & 0.35 \\
\hline$\theta_{\mathrm{F}}[-]$ & $\mathrm{G}, \mathrm{S}$ & 0.15 & 0.15 & 0.25 & 0.15 & 0.35 \\
\hline
\end{tabular}

Table 1: Characteristic parameters $\left(K\right.$ : hydraulic conductivity, $H_{\text {mean }}$ : mean thickness of the zone, $\theta$ : effective porosity; subscript W: weathered zone, subscript F: fractured zone) of the five models (REF: reference model, THICK: model with thicker weathered zone, THIN: model with thinner weathered zone, AHC: model with higher hydraulic conductivity in granite, HOM: homogeneous model). 


\begin{tabular}{|c|c|c|c|c|c|}
\hline & REF & THICK & THIN & AHC & HOM \\
\hline groundwater discharge $\left[\mathrm{m}^{3} \mathrm{~d}^{-1}\right]$ & $1.25 \times 10^{4}$ & $1.27 \times 10^{4}$ & $1.23 \times 10^{4}$ & $1.23 \times 10^{4}$ & $1.28 \times 10^{4}$ \\
\hline$\varepsilon[\%]$ & 1.8 & 3.2 & 0.2 & 0.2 & 3.8 \\
\hline groundwater age, mean [y] & 37.5 & 37.7 & 38.1 & 37.8 & 38.5 \\
\hline$\varepsilon[\%]$ & 3.6 & 3.1 & 2.0 & 2.8 & 1.0 \\
\hline groundwater age, SD [y] & 6.2 & 6.8 & 7.6 & 6.6 & 5.8 \\
\hline$\varepsilon[\%]$ & 13.9 & 5.5 & 5.5 & 8.3 & 19.4 \\
\hline
\end{tabular}

Table 2: Groundwater discharge, mean and standard deviation of groundwater ages of the five models (REF: reference model, THICK: model with thicker weathered zone, THIN: model with thinner weathered zone, AHC: model with higher hydraulic conductivity in granite, HOM: homogeneous model). $\varepsilon$ is the relative error between the modeled and measured values. Measured baseflow $=1.24 \times 10^{4} \mathrm{~m}^{3} \mathrm{~d}^{-1}$, mean of the sampled groundwater ages $=38.9 \mathrm{y}$, standard deviation of the sampled groundwater ages $=7.2 \mathrm{y}$. 


\begin{tabular}{|c|c|c|c|c|c|c|}
\hline & & REF & $\mathrm{HOM}$ & THIN & THICK & $\mathrm{AHC}$ \\
\hline \multirow{4}{*}{ catchment } & mean distance $[\mathrm{m}]$ & 334 & 358 & 323 & 307 & 438 \\
\hline & CV distance [\%] & 59 & 62 & 60 & 65 & 57 \\
\hline & mean time $[y]$ & 51 & 148 & 65 & 55 & 53 \\
\hline & CV time [\%] & 29 & 26 & 31 & 26 & 30 \\
\hline \multirow{4}{*}{ lowland } & mean distance $[\mathrm{m}]$ & 219 & 285 & 214 & 300 & 202 \\
\hline & CV distance [\%] & 59 & 52 & 62 & 48 & 0.72 \\
\hline & mean time $[y]$ & 47 & 141 & 62 & 52 & 53 \\
\hline & CV time [\%] & 34 & 26 & 35 & 23 & 48 \\
\hline \multirow{4}{*}{ transition } & mean distance $[\mathrm{m}]$ & 576 & 713 & 572 & 639 & 398 \\
\hline & $\mathrm{CV}$ distance [\%] & 49 & 35 & 49 & 34 & 44 \\
\hline & mean time $[y]$ & 57 & 171 & 75 & 51 & 53 \\
\hline & CV time $[\%]$ & 44 & 28 & 43 & 27 & 32 \\
\hline \multirow{4}{*}{ upland } & mean distance $[\mathrm{m}]$ & 326 & 296 & 313 & 223 & 566 \\
\hline & CV distance [\%] & 40 & 47 & 41 & 48 & 38 \\
\hline & mean time $[y]$ & 51 & 146 & 64 & 58 & 53 \\
\hline & CV time $[\%]$ & 18 & 24 & 21 & 26 & 14 \\
\hline
\end{tabular}

Table 3: Groundwater mean distances and mean transit times and their coefficient of variation for each of the five groundwater flow models (REF: reference model, THICK: model with thicker weathered zone, THIN: model with thinner weathered zone, AHC: model with higher hydraulic conductivity in granite, HOM: homogeneous model). 


\begin{tabular}{|c|c|c|c|c|c|}
\hline & REF & THICK & THIN & AHC & HOM \\
\hline catchment [\%] & 77 & 85 & 85 & 68 & 82 \\
\hline upland [\%] & 97 & 94 & 98 & 100 & 96 \\
\hline lowland [\%] & 70 & 82 & 79 & 56 & 76 \\
\hline
\end{tabular}

Table 4: Intersection rate of the groundwater table with the surface at stream channels for the five models (REF: reference model, THICK: model with thicker weathered zone, THIN: model with thinner weathered zone, AHC: model with higher hydraulic conductivity in granite, HOM: homogeneous model). Rate is expressed as the percentage of the connected length to the full stream length. 


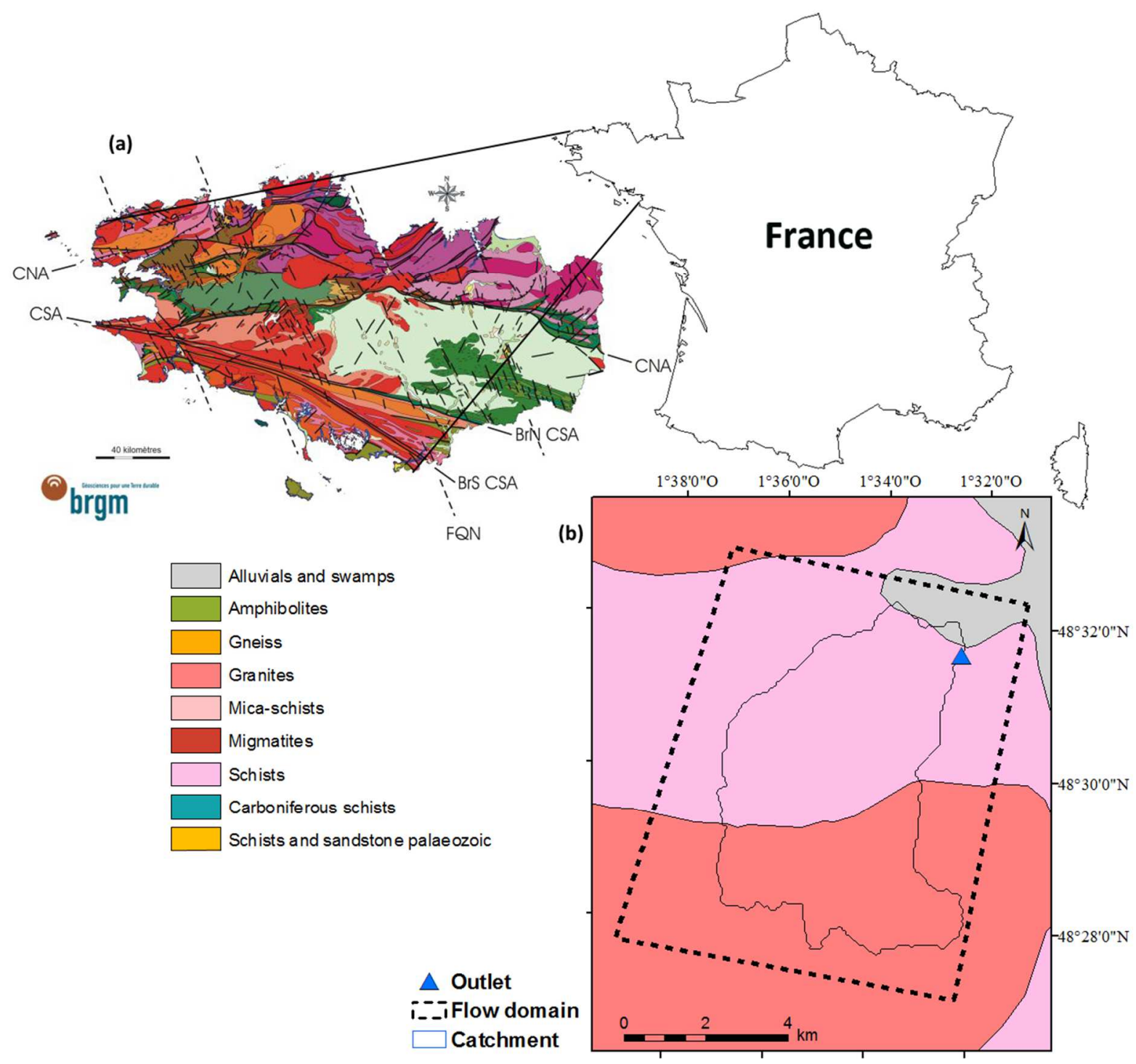




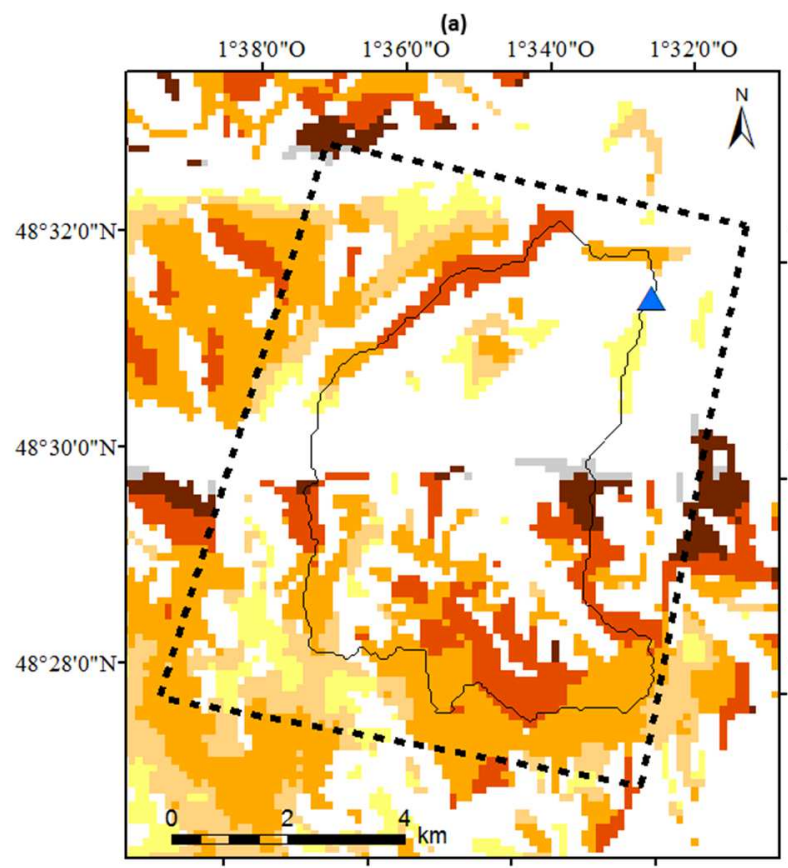

Weathered

material

thickness (m) No $\begin{array}{llllll}40 & 30 & 20 & 10 & 5 & 0\end{array}$ data
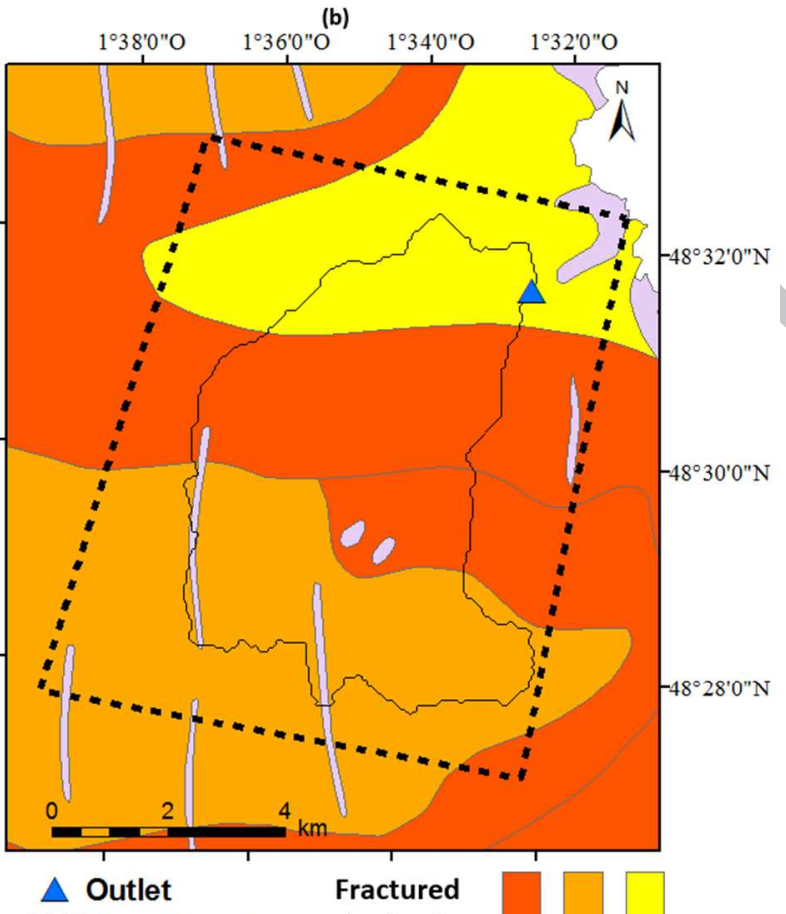

i--iFlow domain

Catchment

bedrock

thickness (m) $50 \quad 40 \quad 30$ 


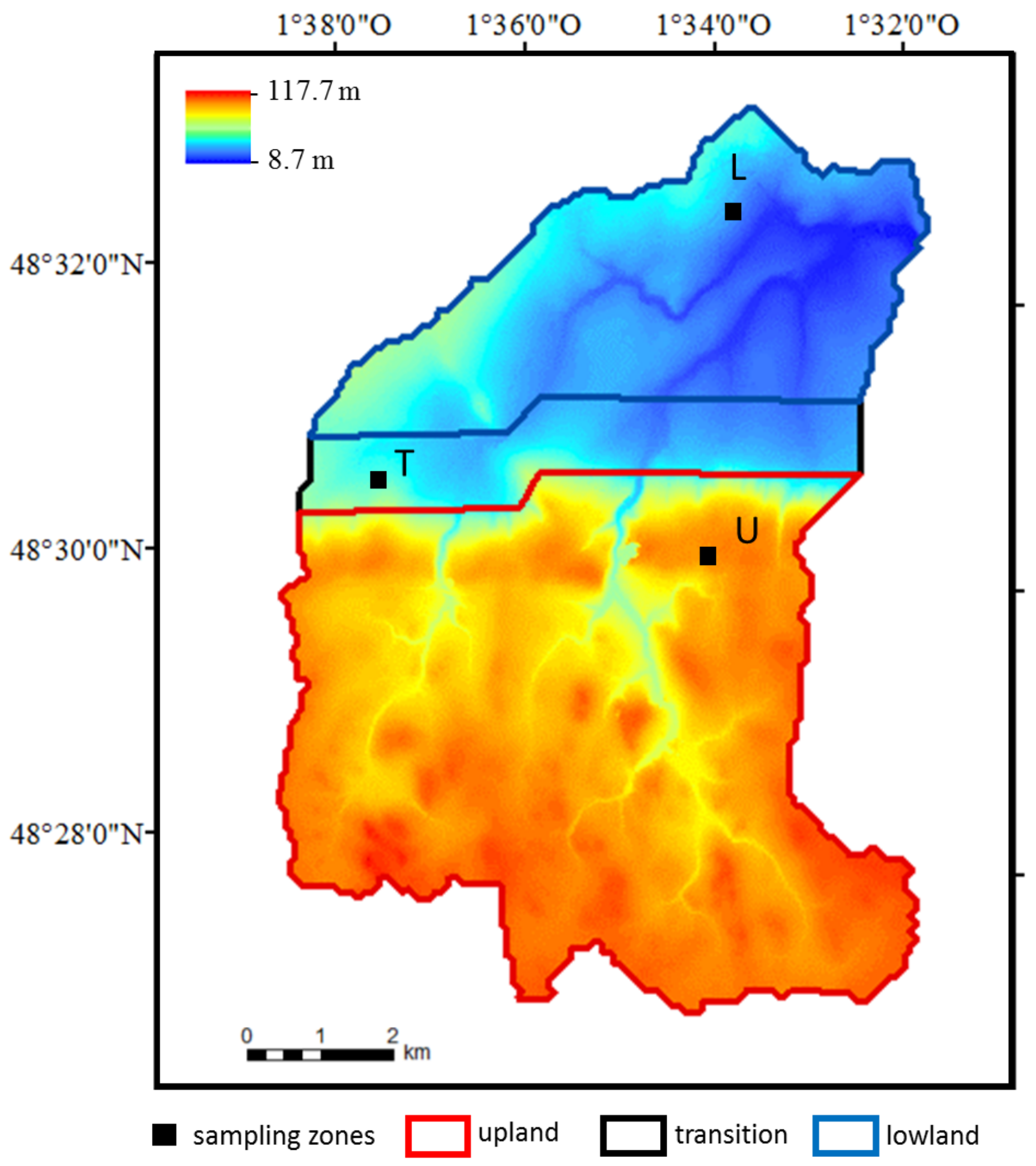




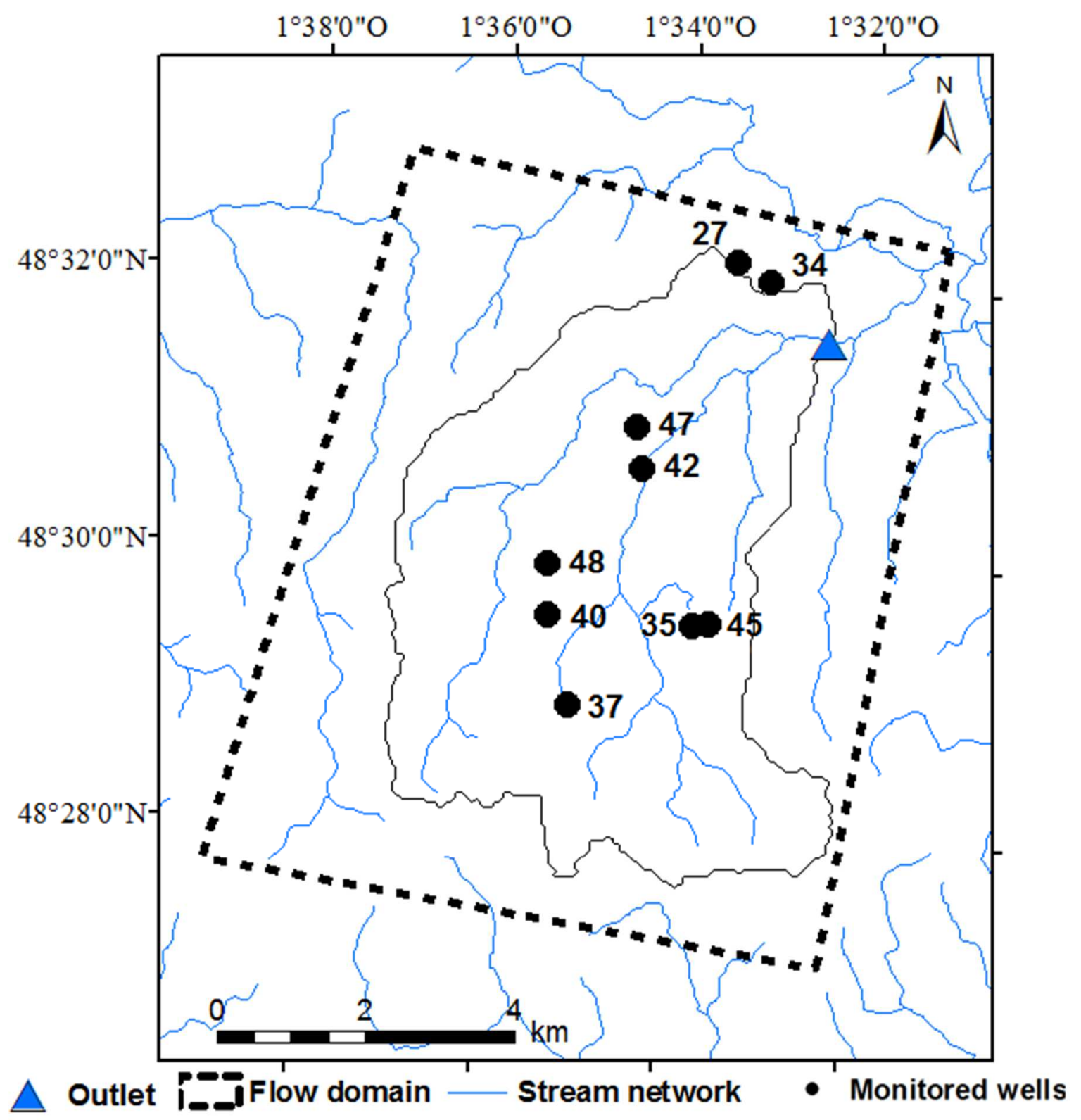


Hydraulic head (m)

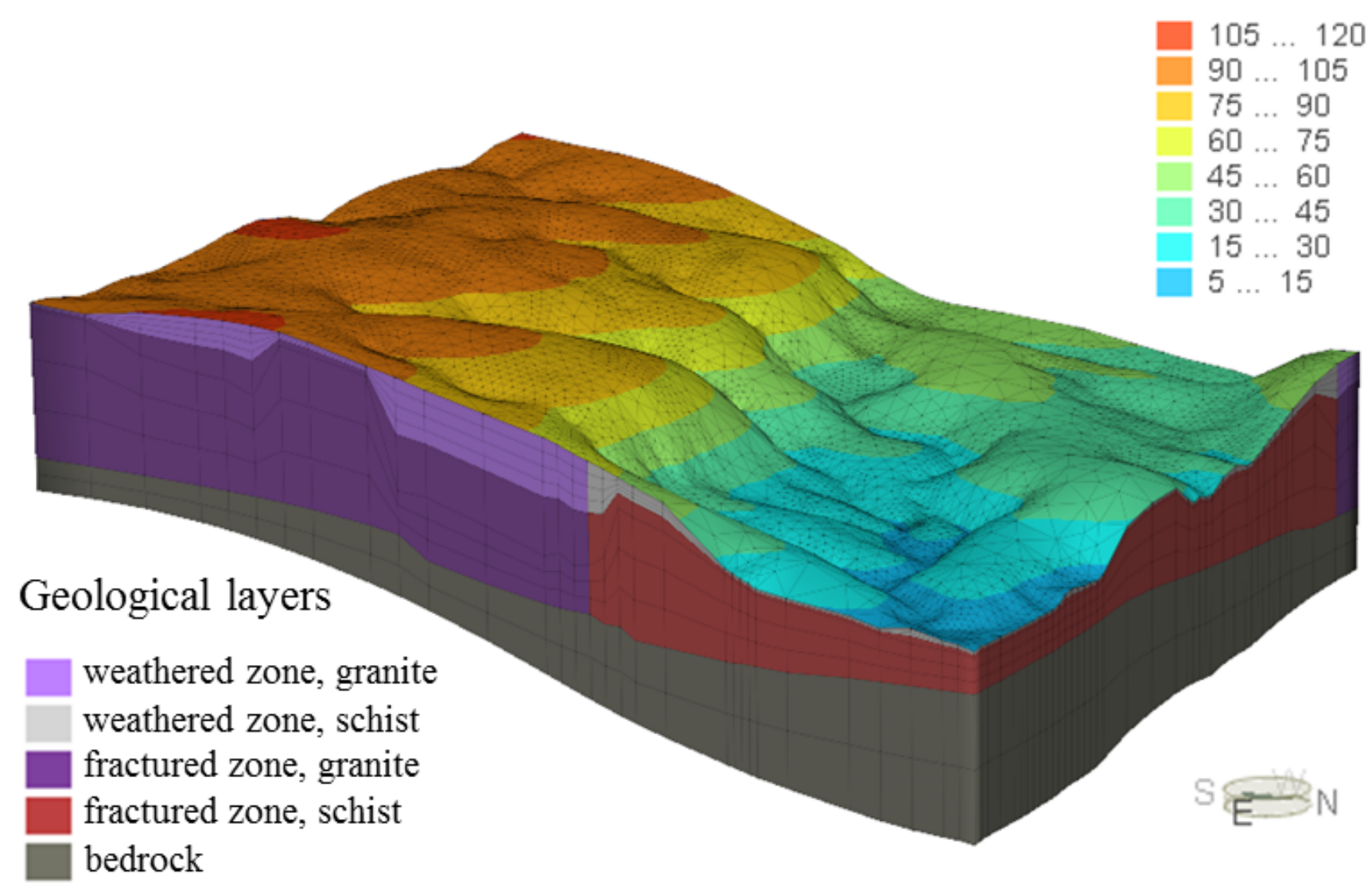

$105 \ldots 120$

$75 \ldots 90$

$60 \ldots 75$

$45 \ldots 60$

$30 \ldots 45$

$15 \ldots 30$

Geological layers

weathered zone, granite weathered zone, schist fractured zone, granite fractured zone, schist bedrock 


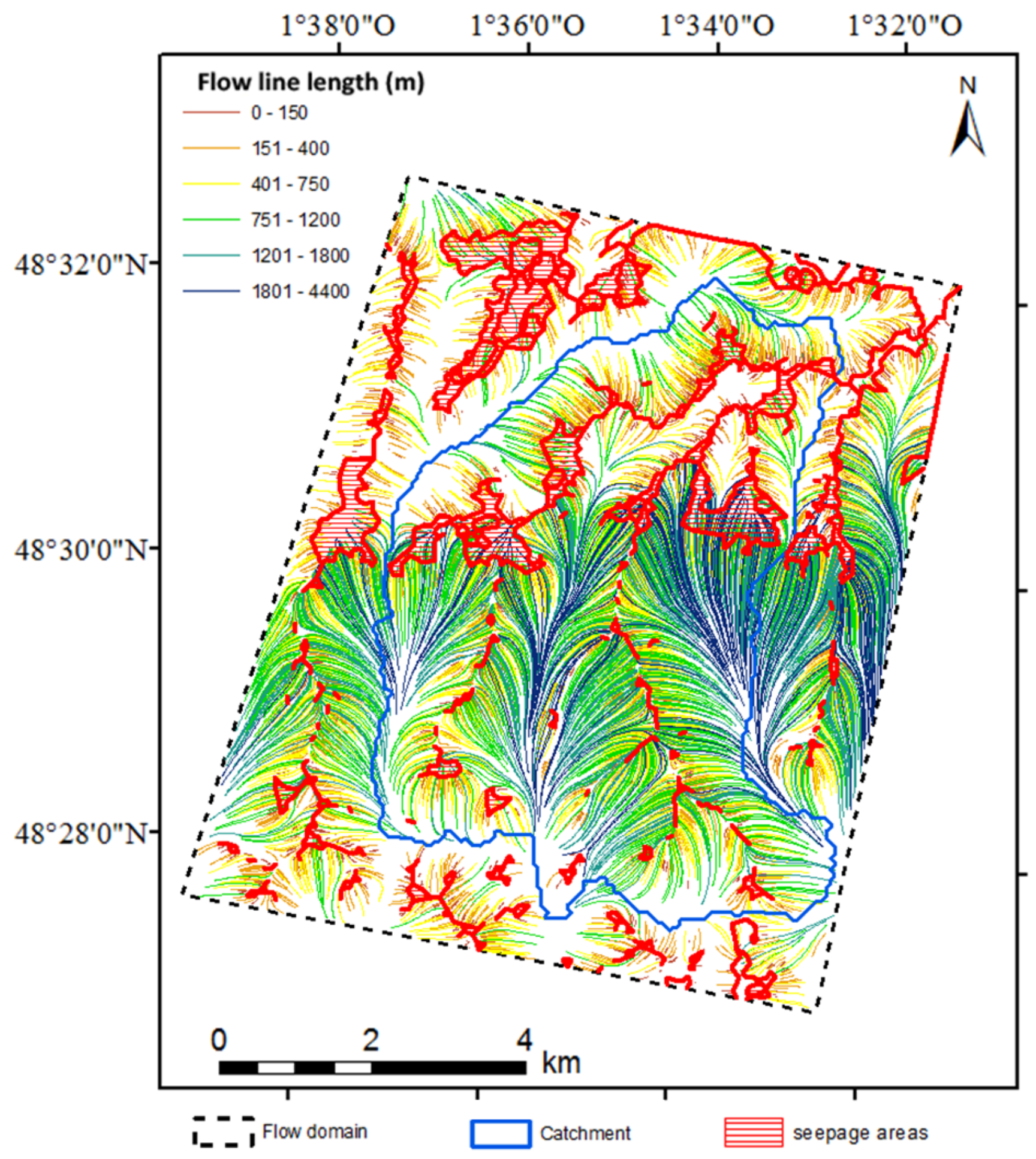



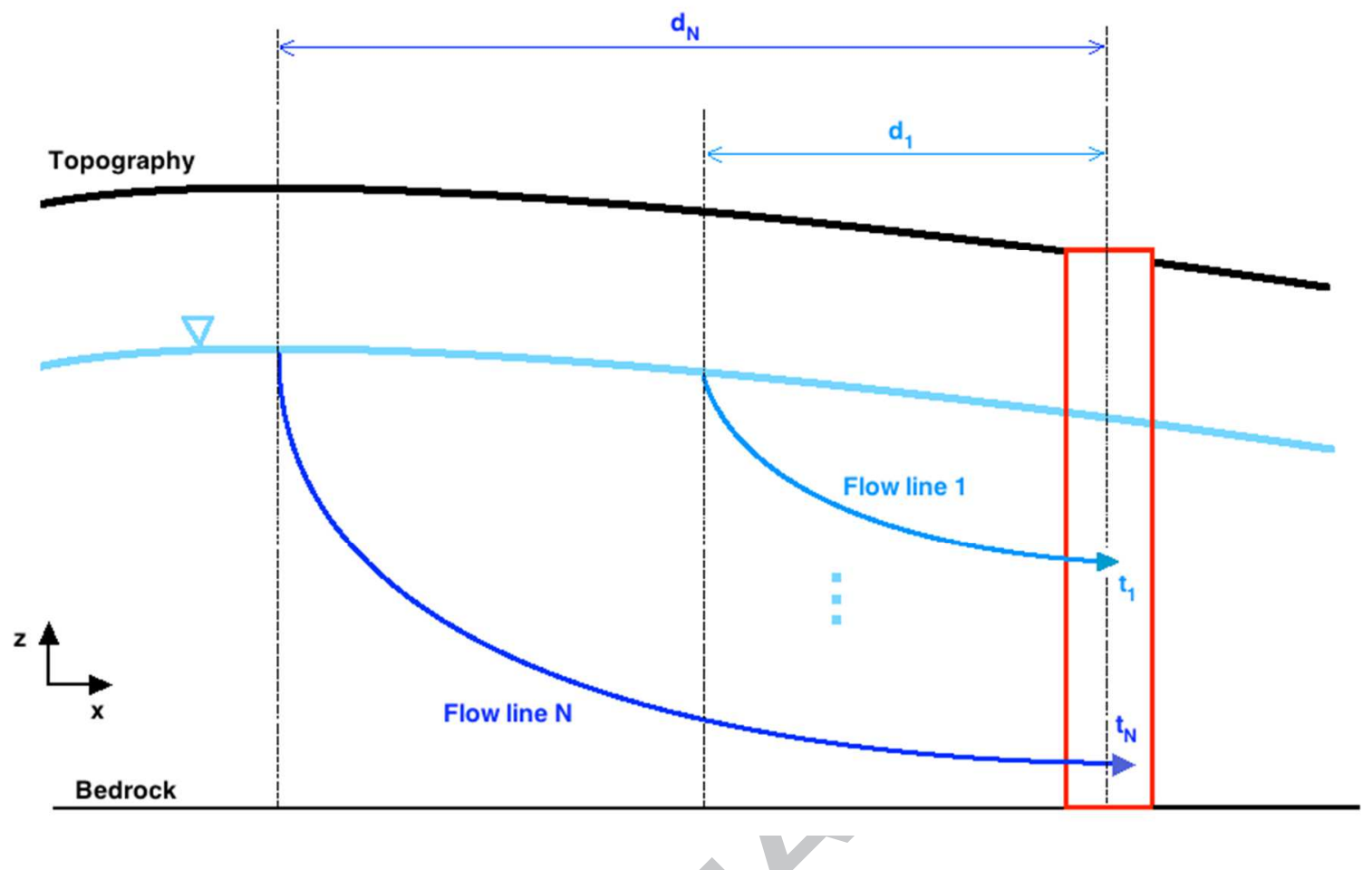
(a)

reference distance,

groundwater travel distance

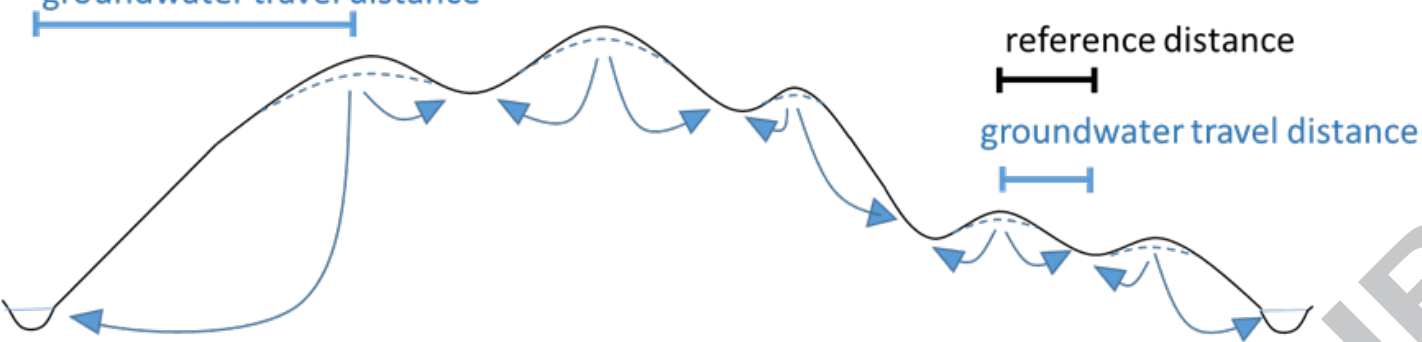

saturated zones filles MORE than $95 \%$

of the subsurface volume

TOPOGRAPHY CONTROLLED

$\mathbf{r}_{\text {GW-LOCAL }}=\mathbf{1}$

groundwater travel distance $=$ reference distance
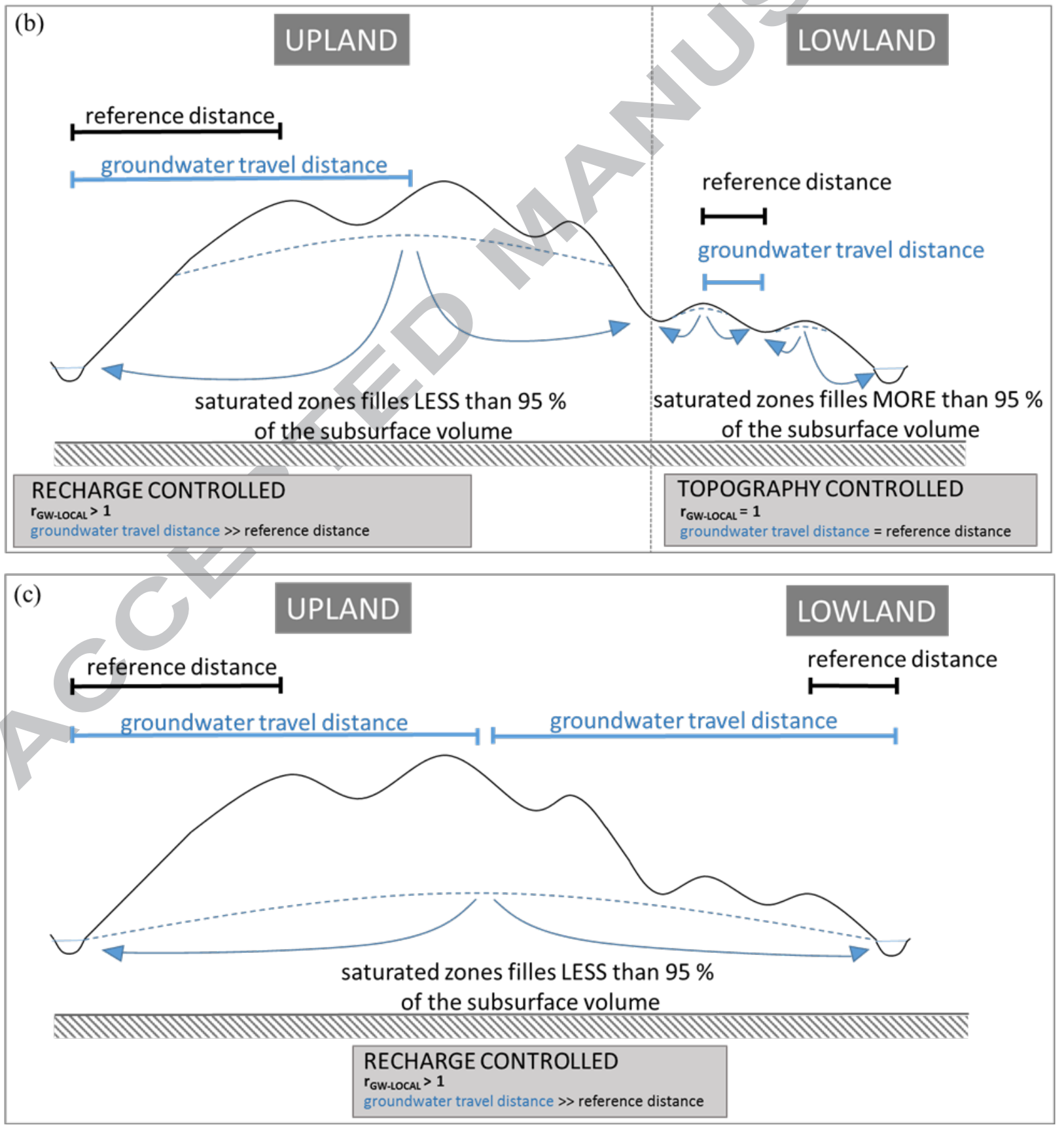
(a)

ACCEPTED MANUSCRIPT

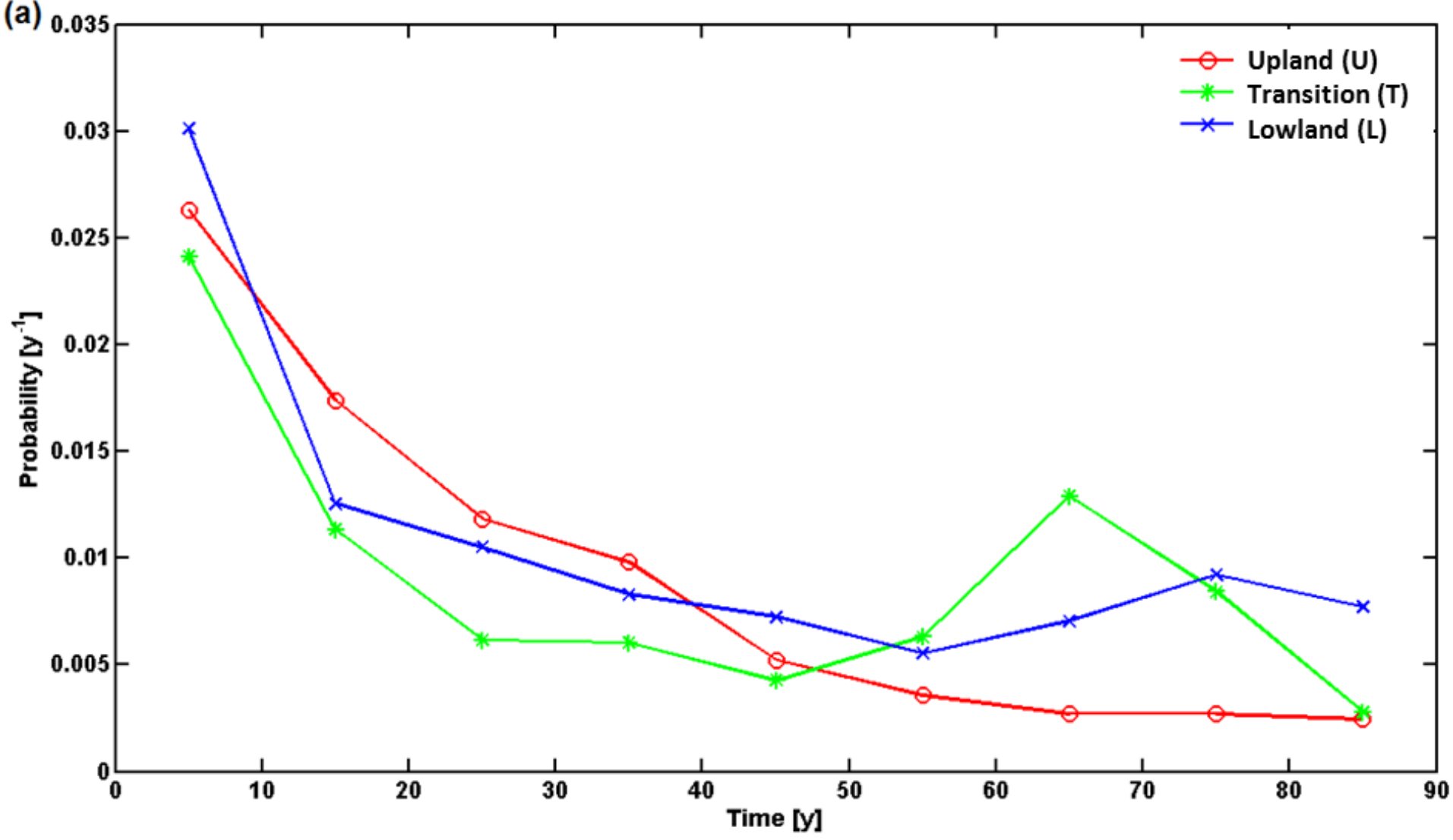

(b)

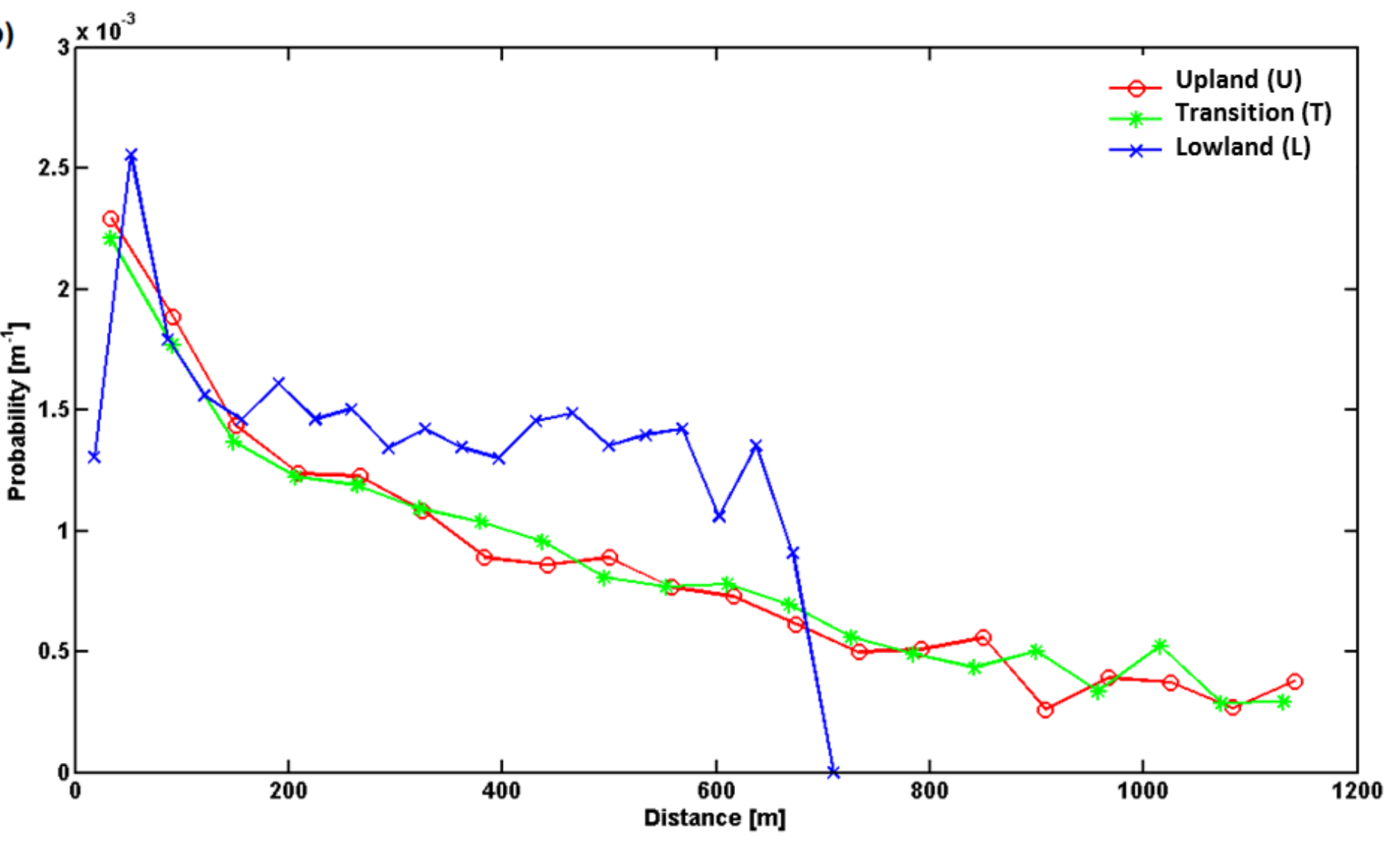




\section{(a) $1^{\circ} 38^{\prime} 0^{\circ} \mathrm{O}$}

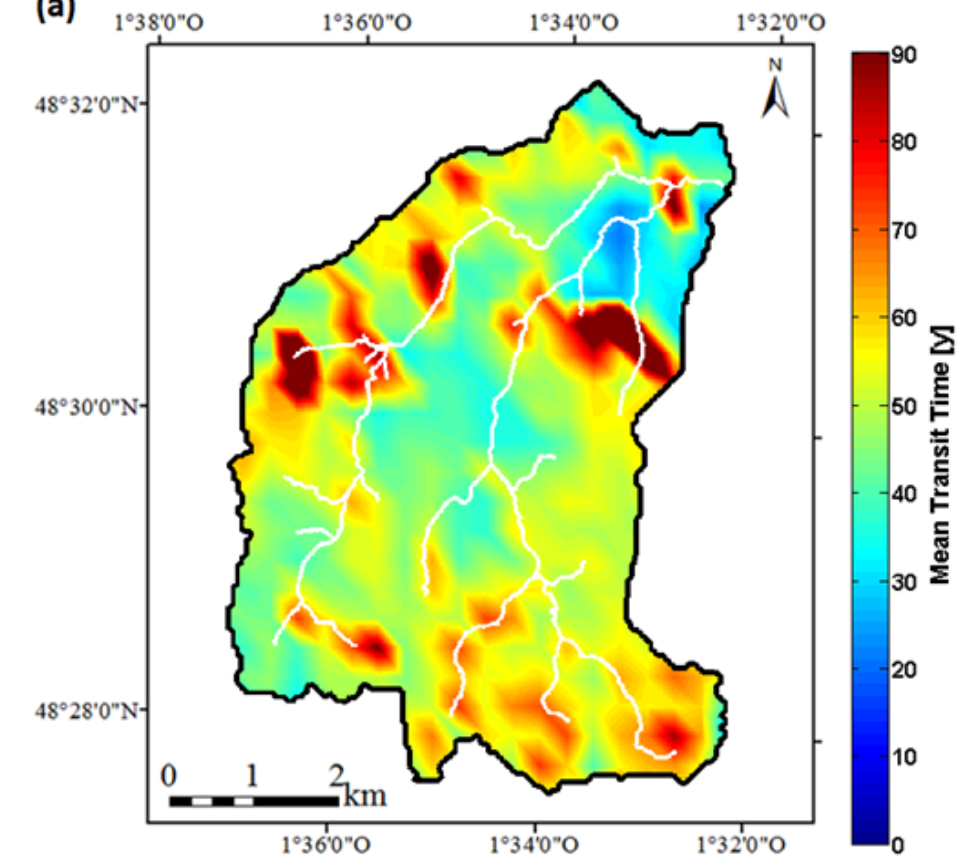

(b)

(b) $1^{\circ} 38^{\circ} 0^{\circ} \mathrm{O}$

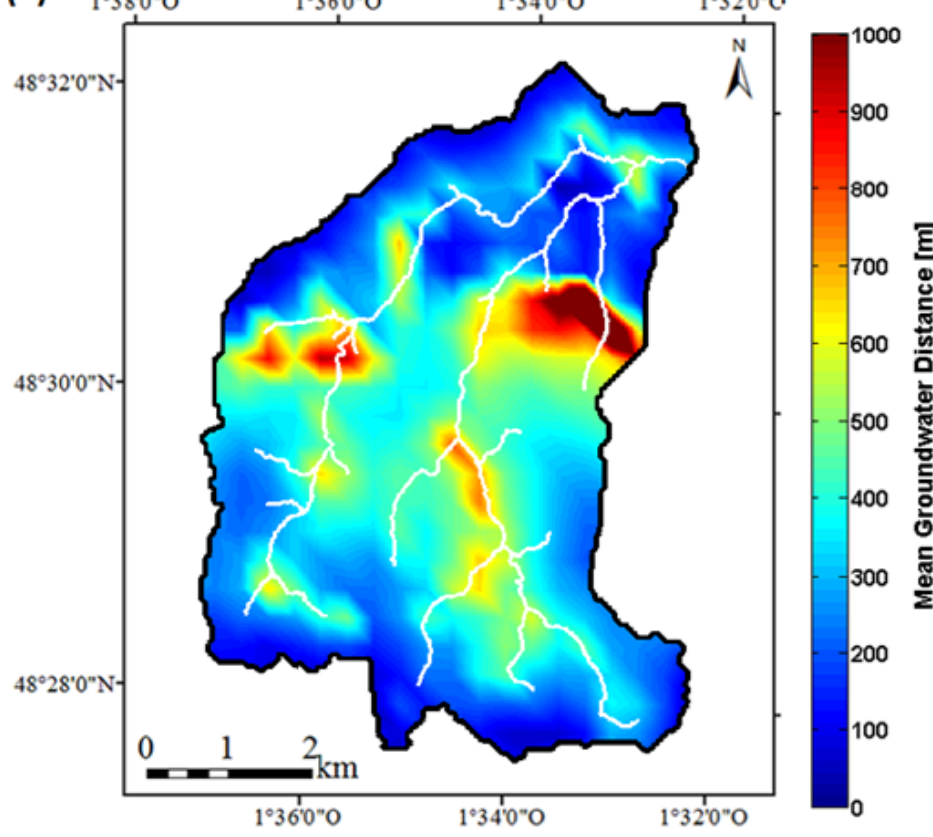


Figure11

ACCEPTED MANUSCRIPT
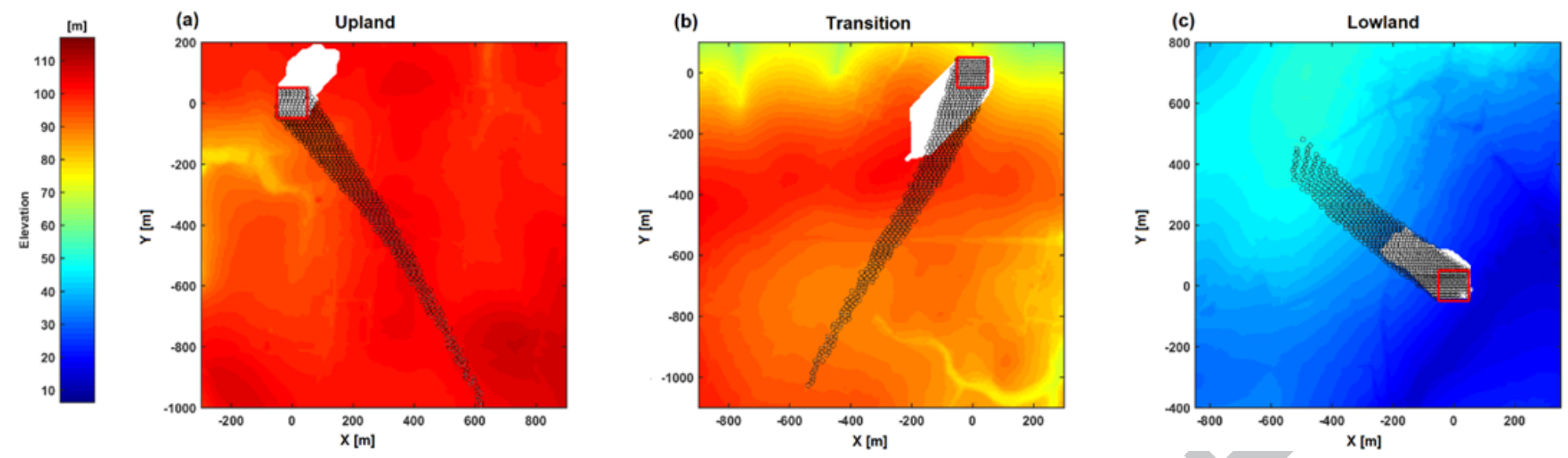


\section{ACCEPTED MANUSCRIPT}
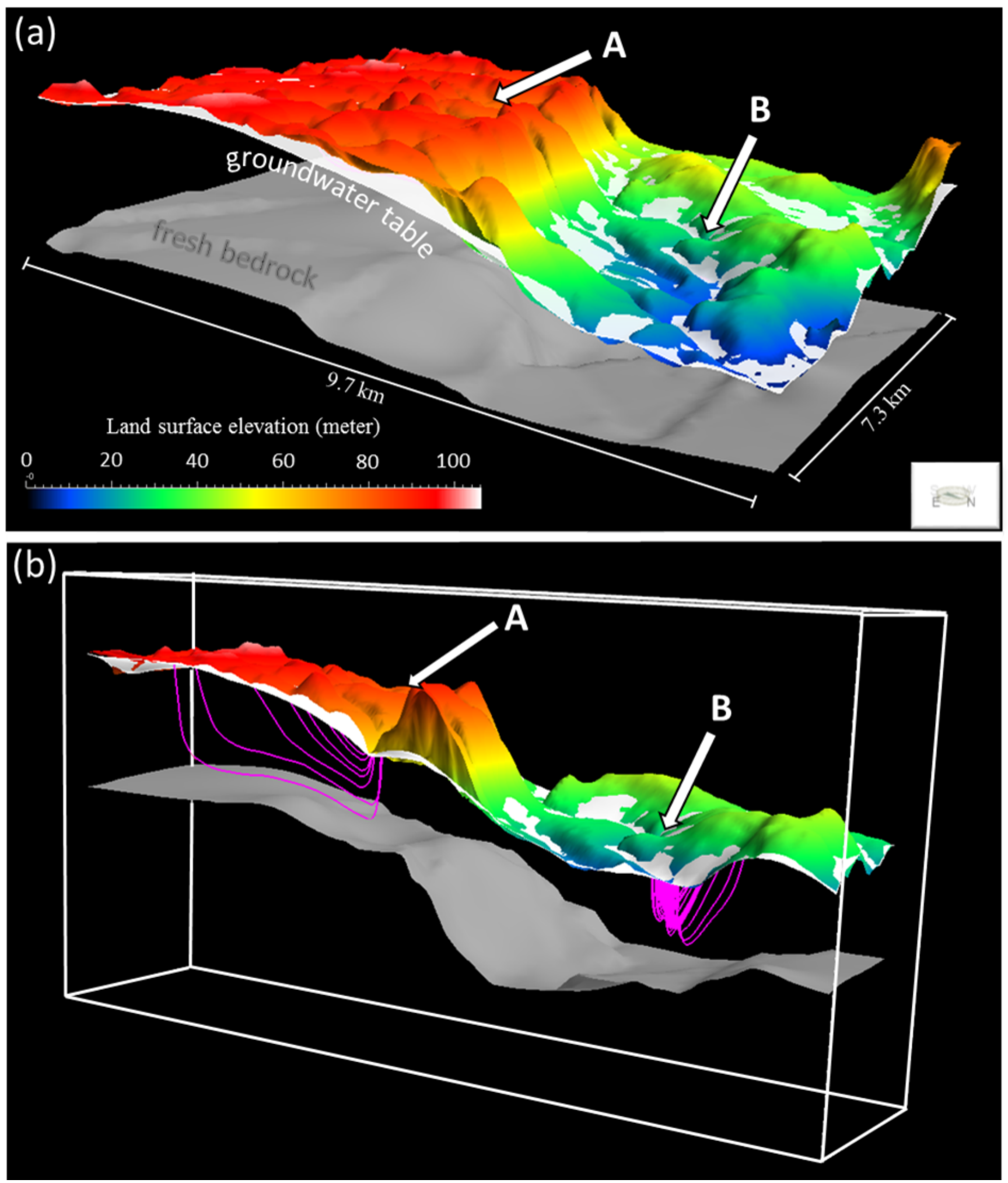
Figure13

(a) $\mathrm{REF}$ (4R)

(b)

$\mathrm{REF}(\mathrm{R})$

(c)

$\operatorname{REF}(\mathrm{R} / 10)$
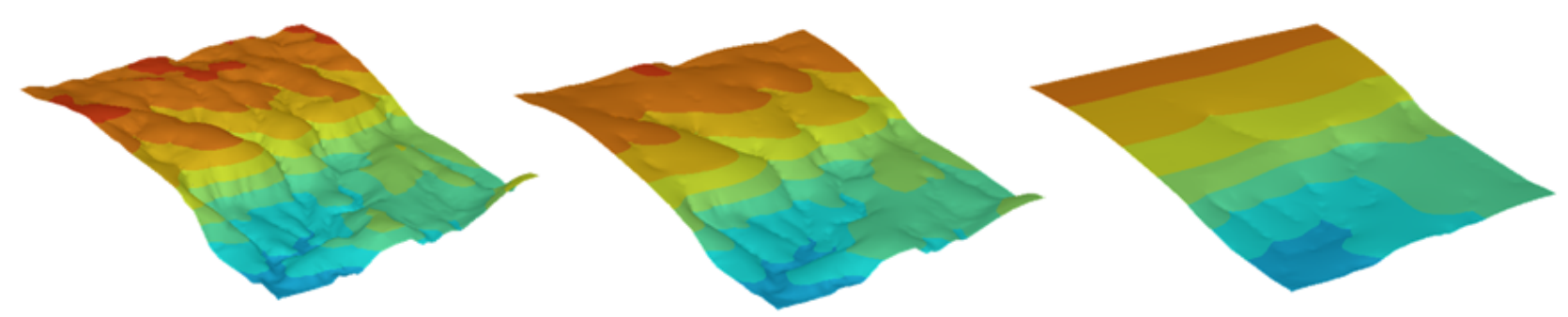

Groundwater

table elevation (m)
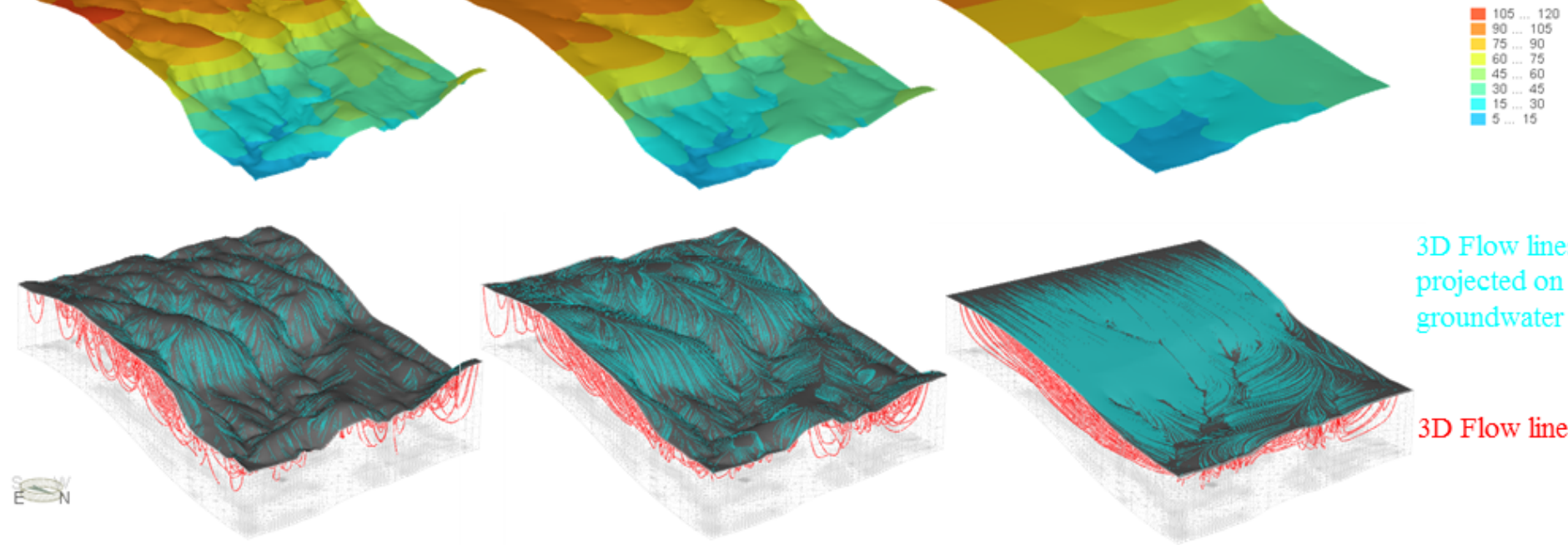

3D Flow lines

projected on the

groundwater table

3D Flow lines 


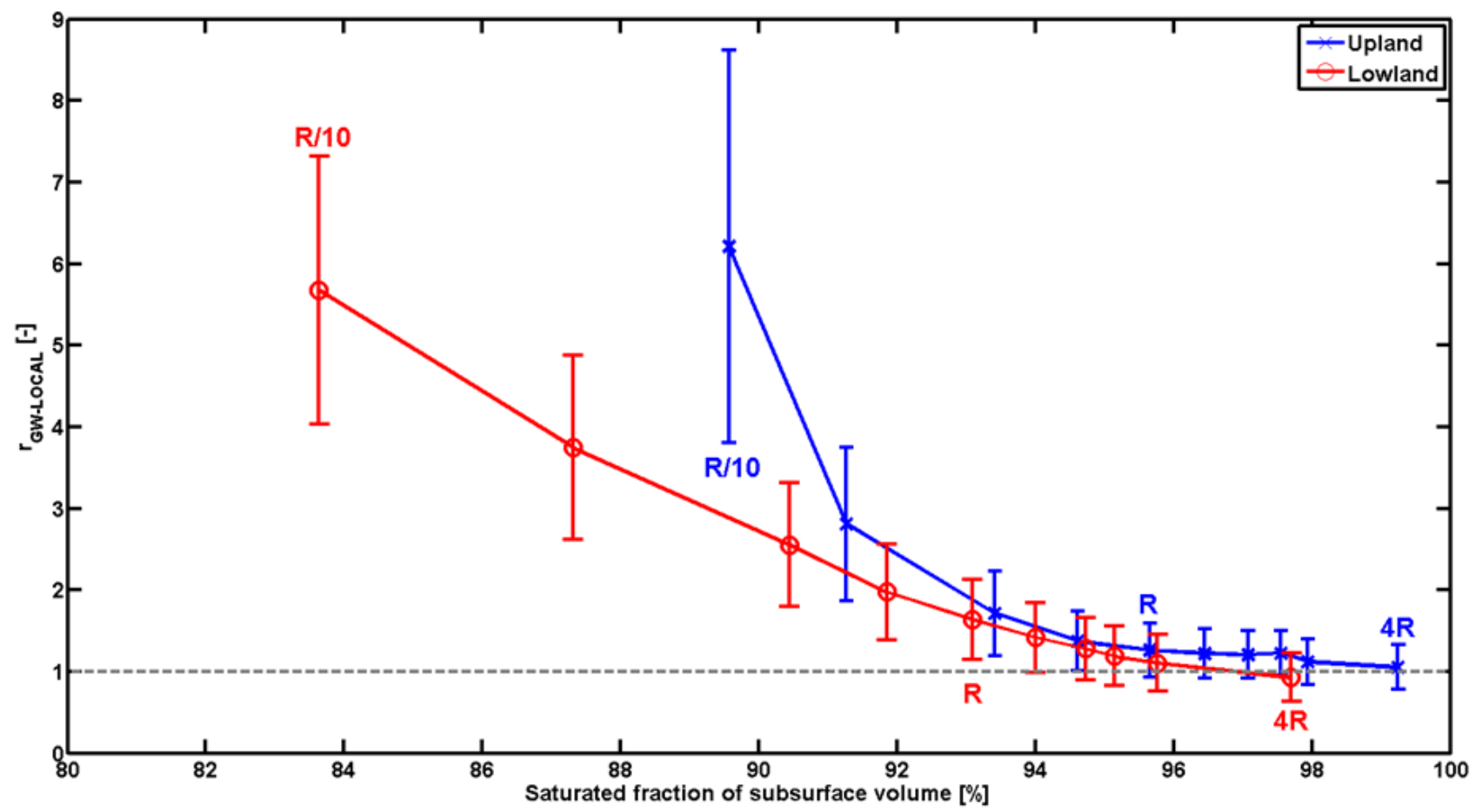




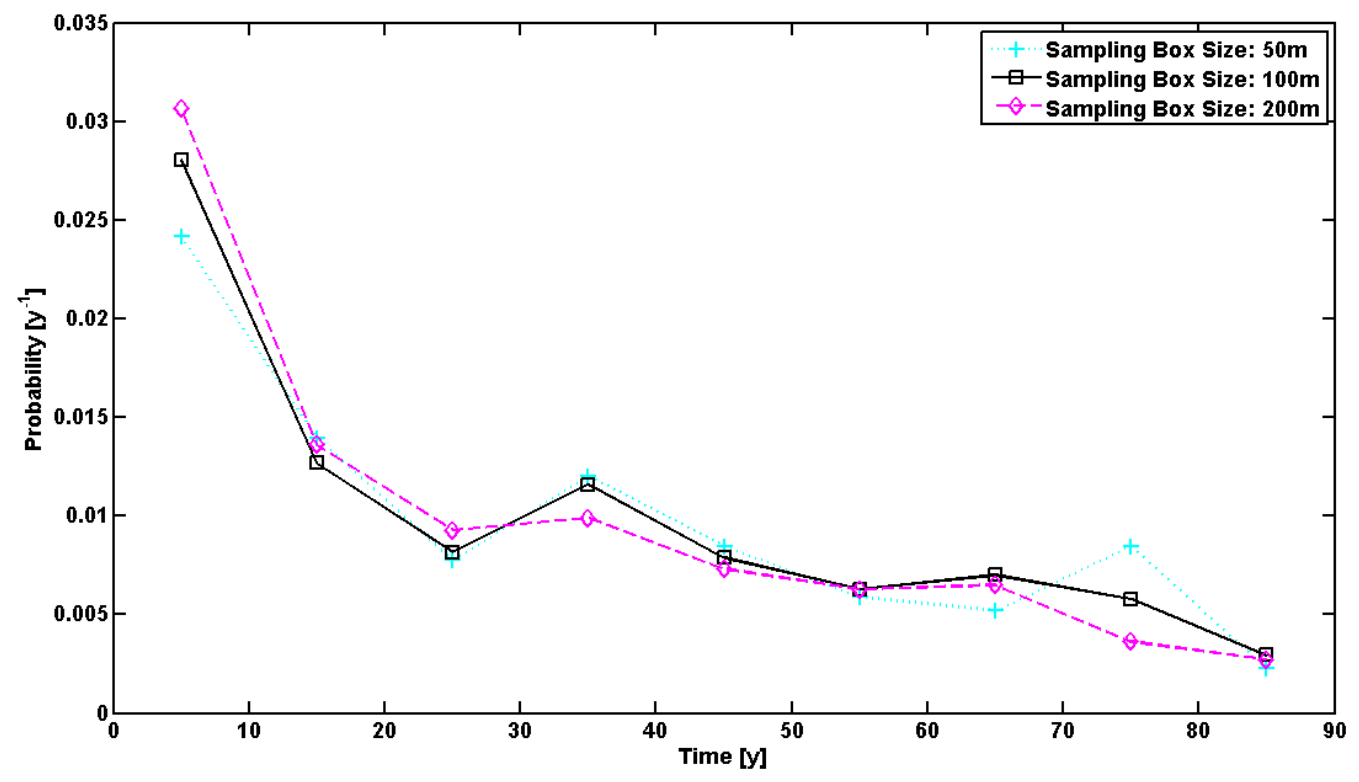




\section{Highlights}

- Groundwater circulation remains local in small crystalline aquifers

- Transit times are large despite highly local flow

- Groundwater distance distribution decreases at downslope sites

- An indicator of groundwater table controls at the small catchment scale is proposed

- Groundwater quality should be investigated at local scales in shallow aquifers 